\title{
Spatial variability and the fate of cesium in coastal sediments near Fukushima, Japan
}

\author{
E. E. Black and K. O. Buesseler \\ Woods Hole Oceanographic Institution, 266 Woods Hole Road, Mail Stop \#25, Woods Hole, MA 02543-1050, USA \\ Correspondence to: E. E. Black (eblack@whoi.edu) and K. O. Buesseler (kbuesseler@whoi.edu)
}

Received: 12 February 2014 - Published in Biogeosciences Discuss.: 20 May 2014

Revised: 8 August 2014 - Accepted: 21 August 2014 - Published: 23 September 2014

\begin{abstract}
Quantifying the amount of cesium incorporated into marine sediments as a result of the Fukushima Dai-ichi Nuclear Power Plant (FDNPP) accident has proven challenging due to the limited multi-core sampling from within the $30 \mathrm{~km}$ zone around the facility; the inherent spatial heterogeneities in ocean sediments; and the potential for inventory fluctuations due to physical, biological, and chemical processes. Using ${ }^{210} \mathrm{~Pb},{ }^{234} \mathrm{Th},{ }^{137} \mathrm{Cs}$, and ${ }^{134} \mathrm{Cs}$ profiles from 20 sediment cores, coastal sediment inventories were reevaluated. A ${ }^{137} \mathrm{Cs}$ sediment inventory of $100 \pm 50 \mathrm{TBq}$ was found for an area of $55000 \mathrm{~km}^{2}$ using cores from this study and a total of $130 \pm 60 \mathrm{TBq}$ using an additional 181 samples. These inventories represent less than $1 \%$ of the estimated $15-30 \mathrm{PBq}$ of cesium released during the FDNPP disaster. The time needed for surface sediment activities $(0$ to $3 \mathrm{~cm})$ at the 20 locations to be reduced by $50 \%$ via sediment mixing was estimated to range from 0.4 to $26 \mathrm{yr}$. Due to the observed variability in mixing rates, grain size, and inventories, additional cores are needed to improve these estimates and capture the full extent of cesium penetration into the shallow coastal sediments, which was deeper than $14 \mathrm{~cm}$ for all cores retrieved from water depths less than $150 \mathrm{~m}$.
\end{abstract}

\section{Introduction}

The Tohoku earthquake and tsunami of 11 March 2011 led to multiple system failures at the Fukushima Dai-ichi Nuclear Power Plant (FDNPP). Over the next month, cooling water releases and hydrogen explosions resulted in the largest nuclear disaster since Chernobyl. Oceanic inputs included direct cooling discharge, runoff, riverine flow, and an estimated 70 to $80 \%$ of the total atmospheric radionuclide release
(Aoyama et al., 2012). While later reports indicate additional releases to the ocean (TEPCO, 2014; Kanda, 2013), the initial ${ }^{137} \mathrm{Cs}$ activities measured in the FDNPP discharge channel from March to May of 2011 represent the most significant oceanic contribution to date, peaking at 68 million $\mathrm{Bq} \mathrm{m}^{-3}$ on 6 April 2011 (Buesseler et al., 2011). ${ }^{137}$ Cs emerged as the major oceanic contaminant, warranting long-term study due to its $\sim 30 \mathrm{yr}$ half-life and large release, generally estimated to be around 15-30 PBq (Buesseler, 2014; Charette et al., 2013; Povinec et al., 2013; Chino et al., 2011; Stohl et al., 2011). ${ }^{137} \mathrm{Cs}$ and ${ }^{134} \mathrm{Cs}\left(t_{1 / 2} \sim 2\right.$ years $)$ have been found with comparable activities near the FDNPP and were released with a ratio of $\sim 1$ (Buesseler et al., 2011). Although the isotopes are highly soluble in the coastal ocean (Buesseler et al., 2012), a small percentage of the release will have been incorporated into the marine sediments and may remain associated with the seafloor, even after currents transport much of the dissolved phase away from the coast. Initial studies of the sediments near the FDNPP have shown the widespread incorporation of ${ }^{137} \mathrm{Cs}$ well above the relatively small remaining 1960s fallout signal of $1-2 \mathrm{~Bq} \mathrm{~kg}^{-1}$ (dry) (NRA, 2014b; Kusakabe et al., 2013; Otosaka and Kato, 2014; Otosaka and Kobayashi, 2013).

The most spatially and temporally extensive sediment data sets have been provided by the Ministry of Education, Culture, Sports, Science and Technology of Japan (MEXT) and the Tokyo Electric Power Company (TEPCO). TEPCO initially reported some of the highest ${ }^{134} \mathrm{Cs}$ sediment activities in July of 2011 (TEPCO station 1 at $9600 \mathrm{~Bq} \mathrm{~kg}^{-1}$ wet) in grab samples collected within the $30 \mathrm{~km}$ zone around the FDNPP (NRA, 2014a). However, lacking bulk density measurements, inventory estimates have not been published for this region. MEXT, on the other hand, reported monthly 
multi-corer, dry activities for homogenized 0 to $3 \mathrm{~cm}$ core tops from outside the $30 \mathrm{~km}$ zone (NRA, 2014b). Kusakabe et al. (2013) used 30 different MEXT locations ranging from 45 to $675 \mathrm{~m}$ water depth to estimate a ${ }^{137} \mathrm{Cs}$ sediment inventory of $38 \mathrm{TBq}$ for the top $3 \mathrm{~cm}$. As both data sets are limited to the uppermost layers of the sediment column, calculations using only these measurements will underestimate the total incorporation of cesium into the sediments. In a more recent effort, Otosaka and Kato (2014) paired MEXT cores with $10 \mathrm{~cm}$ Smith-McIntyre grab samples and sectioned cores ranging from 3 to $10 \mathrm{~cm}$ and estimated a ${ }^{134} \mathrm{Cs}$ coastal inventory of $200 \pm 60 \mathrm{TBq}$, decay-corrected to March 2011 .

Larger data sets are essential for more accurate sediment inventory calculations due to the spatial variability and local heterogeneity observed in previous coastal sediment studies from this region (Kusakabe et al., 2013; Thornton et al., 2013). Kusakabe et al. (2013) found a ${ }^{137} \mathrm{Cs}$ activity range of 170 to $580 \mathrm{~Bq} \mathrm{~kg}^{-1}$ with six successive multicorer casts at nominally the same sampling site (mean and standard deviation of $330 \pm 160 \mathrm{~Bq} \mathrm{~kg}^{-1}$ dry). In addition, Thornton et al. (2013) reported activity fluctuations of $<10$ to $1500 \mathrm{~Bq} \mathrm{~kg}^{-1}$ at sites located between 5 and $10 \mathrm{~km}$ of the FDNPP and from 500 to $40000 \mathrm{~Bq} \mathrm{~kg}^{-1}$ within $3 \mathrm{~km}$ of the FDNPP. These local anomalies were observed over distances of less than $1 \mathrm{~km}$ using a continuous (1 hertz) towed gamma ray spectrometer and their magnitude illustrates the importance of high-spatial-resolution sampling.

The evolution and ultimate fate of cesium isotopes in the coastal ocean must be better constrained to assess both the short-term implications of the FDNPP accident and the potential for lasting effects. Reports that bottom-water fish contain higher cesium concentrations than pelagic fish suggest that the sediments could be a continued source to bottomdwelling biota (Buesseler, 2012). A model study of the coastal food chain near Fukushima indicated that an additional contamination source beyond ocean water, mostly likely associated with the sediments, would be necessary to sustain the cesium levels observed in higher-trophic organisms (Tateda et al., 2013).

${ }^{210} \mathrm{~Pb}\left(t_{1 / 2} \sim 22.2\right.$ years $)$ and ${ }^{234} \mathrm{Th}\left(t_{1 / 2} \sim 24\right.$ days $)$, naturally occurring daughter products in the ${ }^{238} \mathrm{U}$ decay series, can aid in evaluating the rates of sedimentation and bioturbation occurring in sediments from months to decades (Yang et al., 1985). ${ }^{234} \mathrm{Th}$ is particle reactive and will be scavenged easily in the upper ocean, leading to a potential excess in sediments $\left({ }^{234} \mathrm{Th}_{\mathrm{ex}}\right)$. Because of its short half-life, measurable ${ }^{234} \mathrm{Th}_{\mathrm{ex}}$ is generally only observed in the top few $\mathrm{cm}$ of the sediment column in areas of rapid and recent mixing. Excess ${ }^{210} \mathrm{~Pb}\left({ }^{210} \mathrm{~Pb}_{\mathrm{ex}}\right)$ is supplied via atmospheric deposition, from the decay of ${ }^{222} \mathrm{Rn}$ gas, and scavenging in the water column. In sediments ${ }^{210} \mathrm{~Pb}_{\mathrm{ex}}$ represents the divergence from secular equilibrium with ${ }^{226} \mathrm{Ra}$ (supported ${ }^{210} \mathrm{~Pb}$ ). If conditions are relatively stable, the ${ }^{210} \mathrm{~Pb}_{\mathrm{ex}}$ inventory in a given area will represent the flux to this location averaged over the last century ( $\sim 5$ half-lives).

\section{Methods}

\subsection{Sample collection}

Twenty sediment cores ranging in length from 6 to $20 \mathrm{~cm}$ were collected during cruise campaigns in May 2012 (R/V Tansei Maru), June and July 2012 (R/V Mirai), May 2013 (R/V Umitaka Maru), and September 2013 (R/V Daisan Kaiyo Maru). Stations were located 2 to $1865 \mathrm{~km}$ from the FDNPP (Supplement S1). Individual core tubes were retrieved from a multi-corer and cross-sectioned at sea into 0.5 to $2 \mathrm{~cm}$ layers. A sample (plug) of 1 or $7 \mathrm{~cm}^{3}$ was taken from each layer as the cores were cross-sectioned for density calculations. Sediment layers were preserved in sealed bags and the plug samples in capped vials. Eight samples $(0$ to $5 \mathrm{~cm})$ from separate core tubes (R1 to R8) were retrieved from a single cast at the location of core 13 for an analysis of local variability.

\subsection{Grain size analysis}

Grain size analysis was performed on a subset of $\sim 3 \mathrm{~cm}^{3}$ core samples using a Beckman Coulter LS13320 particle size analyzer with capabilities of $0.4 \mu \mathrm{m}$ to $2 \mathrm{~mm}$. Grain size results are reported as percent clay and percent fines (silt plus clay) averaged over the entire depth of each core. Percent clay and percent fines were calculated by summing the frequency outputs from 0 to $3.86 \mu \mathrm{m}$ and from 0 to $63.41 \mu \mathrm{m}$, respectively. D50 values were determined, which signify the grain size at which $50 \%$ of the sample is smaller or larger by particle count. All grain average size results are reported with standard deviations (SDs). Samples from cores 15 and 16 consisted of up to $42 \%$ of grains over $1 \mathrm{~mm}$ by mass and were processed differently due to the counter limitations. To ensure that no prolate grains with a nearly $2 \mathrm{~mm}$ axis passed to the counter, a $1 \mathrm{~mm}$ sieve was placed over the sample delivery system. The total mass of the sample used, ranging from 5 to 45 grams, was determined by the counter's optimal obscuration range or percentage of light blockage by grains (15 to $25 \%$ ).

\subsection{Isotope measurements}

Samples were dried at $40-60{ }^{\circ} \mathrm{C}$ for a minimum of 1 day and analyzed using Canberra GCW4030S germanium gamma well detectors for the following energy peaks: $46.5 \mathrm{keV}$ $\left({ }^{210} \mathrm{~Pb}\right), 63.3 \mathrm{keV}\left({ }^{234} \mathrm{Th}\right), 352 \mathrm{keV}\left({ }^{214} \mathrm{~Pb}\right), 661 \mathrm{keV}\left({ }^{137} \mathrm{Cs}\right)$, and $795 \mathrm{keV}\left({ }^{134} \mathrm{Cs}\right)$. Samples were counted for 7 to $24 \mathrm{~h}$ depending on the time to achieve counting uncertainties of less than $5 \%$ on the primary peaks. Detectors were calibrated using a dilute pitchblende ore standard (US EPA Environmental Monitoring Systems Lab) and river sediment standard (NBS 4350 B). Minimum detectable activities (MDAs) were calculated using $24 \mathrm{~h}$ background spectra and efficiencies based on the average sample mass of 16.75 grams and sample volume of $14.5 \mathrm{~mL}$ (Currie, 1968). The calculated MDAs in $\mathrm{Bq} \mathrm{kg}^{-1}$ 
were $4.2\left({ }^{210} \mathrm{~Pb}\right), 3.2\left({ }^{234} \mathrm{Th}\right), 0.7\left({ }^{214} \mathrm{~Pb}\right), 0.4\left({ }^{137} \mathrm{Cs}\right)$, and $0.8\left({ }^{134} \mathrm{Cs}\right)$. Activities under the MDAs and those with counting uncertainties over $50 \%$ were reported as not detectable (ND). Total uncertainties for a given sample and isotope (in $\mathrm{Bq} \mathrm{kg}^{-1}$ dry) represent the higher of either the counting uncertainty or $7 \%$. The minimum uncertainty $(7 \%)$ is the average percent difference between sample activity results when duplicate measurements were made using the same and different detectors. The total uncertainty is propagated through all activity and inventory calculations for individual sections and full cores.

${ }^{210} \mathrm{~Pb}$ activities were decay-corrected to the collection date and adjusted for supported values from ${ }^{214} \mathrm{~Pb}$ (assumed to be at equilibrium with parent ${ }^{226} \mathrm{Ra}$ ) to determine ${ }^{210} \mathrm{~Pb}_{\text {ex }}$. Since an excess of ${ }^{234} \mathrm{Th}$ generally exists only in the first few centimeters, an estimation of equilibrium ${ }^{234} \mathrm{Th}$ values at depth were used to determine ${ }^{234} \mathrm{Th}_{\text {supported }}$, the activity supported by the decay of its ${ }^{238} \mathrm{U}$ parent, to calculate ${ }^{234} \mathrm{Th}_{\mathrm{ex}}$ (decay-corrected to collection). All ${ }^{134} \mathrm{Cs}$ and ${ }^{137} \mathrm{Cs}$ data were decay-corrected to the date of maximum concentrations at the FDNPP (6 April, 2011; Buesseler et al., 2011). By decay correcting, the changes we observe can be attributed to physical and biological processes and not radioactive decay. All final ${ }^{210} \mathrm{~Pb}_{\mathrm{ex}},{ }^{234} \mathrm{Th}_{\mathrm{ex}}$, and cesium activities for an individual layer are reported as $\mathrm{Bq} \mathrm{kg}^{-1}$ dry, and surface activities were calculated as the weighted (relative to layer thickness) average of layer activities for the top $3 \mathrm{~cm}$ of each core.

Layer inventories in $\mathrm{Bq} \mathrm{m}^{-2}$ were calculated for ${ }^{134} \mathrm{Cs}$, ${ }^{137} \mathrm{Cs},{ }^{210} \mathrm{~Pb}_{\mathrm{ex}}$, and ${ }^{234} \mathrm{Th}_{\mathrm{ex}}$ using the following relationship:

$$
\begin{aligned}
\text { Inventory } & =\text { Layer Thickness } \times \text { Bulk Density } \\
& \times \text { Activity }
\end{aligned}
$$

where layer thickness was in meters, activities were in $\mathrm{Bq} \mathrm{kg}^{-1}$ dry, and bulk density $\left(\mathrm{kg} \mathrm{m}^{-3}\right)$ was equal to the amount of dry mass of sample in the 1 or $7 \mathrm{~cm}^{3}$ plug divided by the total volume. All layer inventories for each isotope were summed to calculate total inventories for each individual core except for ${ }^{234} \mathrm{Th}_{\mathrm{ex}}$, which was only reported for the exponentially decreasing surface activities. Because core lengths ranged from 6 to $20 \mathrm{~cm}$, some core inventories would not be representative of the complete isotope profile at that location if ${ }^{210} \mathrm{~Pb}_{\mathrm{ex}}$ values remained elevated at depth.

We estimated the expected sediment inventories of ${ }^{210} \mathrm{~Pb}_{\mathrm{ex}}$ in the coastal sediments near Fukushima, Japan, using an average ${ }^{210} \mathrm{~Pb}_{\text {ex }}$ atmospheric delivery flux of approximately $200 \mathrm{~Bq} \mathrm{~m}^{-2} \times \mathrm{yr}^{-1}$ to obtain an expected inventory from atmospheric input of $6400 \mathrm{~Bq} \mathrm{~m}^{-2}(200 \times 32$ years, mean life of ${ }^{210} \mathrm{~Pb}$ ). The atmospheric delivery flux estimate was derived from average monthly ${ }^{210} \mathrm{~Pb}$ deposition measurements from 1993 to 2001 for Tokai-mura (Ueno et al., 2003) and from 2000 to 2001 for Tokyo and Sendai (Yamamoto et al., 2006). Since ${ }^{210} \mathrm{~Pb}$ is particle reactive, in situ scavenging provides an additional source, the strength of which is a function of the ${ }^{210} \mathrm{~Pb}:{ }^{226} \mathrm{Ra}$ disequilibrium and water depth over which the deficit is found. Since we do not have ${ }^{210} \mathrm{~Pb}:{ }^{226} \mathrm{Ra}$ profiles, we can only estimate a rough scavenging flux for ${ }^{210} \mathrm{~Pb}$ using a Pacific ${ }^{210} \mathrm{~Pb} /{ }^{226} \mathrm{Ra}$ ratio of 0.75 (Tsunogai and Harada, 1980) with a deep sea ${ }^{226} \mathrm{Ra}$ of approximately $33 \mathrm{dpm}$ per $100 \mathrm{~kg}$ activity $\left(28.5^{\circ} \mathrm{N}\right.$ and $145^{\circ} \mathrm{E}$; Nozaki and Tsunogai, 1976). This flux would be a linear function of water depth $(z)$ over which the disequilibrium applies, and it ranges from 70 to $7000 \mathrm{~Bq} \mathrm{~m}^{-2}$ for depths of 50 to $5000 \mathrm{~m}$ (1-D scavenging supply equal to ${ }^{226} \mathrm{Ra}^{210} \mathrm{~Pb} \times \lambda \times z \times 32$ years). Thus, in most coastal settings, the dominant supply of ${ }^{210} \mathrm{~Pb}$ is atmospheric deposition, whereas inventories are expected to increase with depth in the shelf and slope due to scavenging processes in the water column above. In addition, with a relatively long residence time for scavenging, ocean margins in general are sites of enhanced boundary scavenging of ${ }^{210} \mathrm{~Pb}$ (Cochran et al., 1990).

\subsection{Modeling}

While the mixing of marine sediments often occurs via spatially and temporally variable bioturbation processes, such as non-local transport, the cumulative result of sediment accumulation, mixing, and isotope decay is often modeled as a diffusive process and can be written

$$
\begin{aligned}
& \frac{\partial}{\partial t}\{\rho(1-\phi) \times A\}=\frac{\partial}{\partial x}\left\{D_{\mathrm{B}} \rho(1-\phi) \frac{\partial A}{\partial x}\right\} \\
& -\frac{\partial}{\partial x}\{\rho(1-\phi) w \times A\}+\rho(1-\phi) \lambda A,
\end{aligned}
$$

where $\rho$ represents density, $A$ activity of radionuclide, $t$ time, $w$ sedimentation rate, and $\lambda$ represents the decay constant (Cochran, 1985). To generate mixing rates $\left(D_{\mathrm{B}}\right)$ using this relationship for each core, steady state, constant porosity $(\phi)$, and constant $D_{\mathrm{B}}$ with depth $(x)$ were assumed. Equation (2) can be simplified using these assumptions to

Activity $=A_{o} e^{\frac{w-\sqrt{w^{2}-4 D_{\mathrm{B}} \lambda}}{2 D_{\mathrm{B}}} \cdot x}$,

where $A_{\mathrm{o}}$ is the activity at $x=0$ (Anderson et al., 1988). Sedimentation can be ignored if

$w^{2} \ll 4 D_{\mathrm{B}} \lambda$,

Historical ${ }^{210} \mathrm{~Pb}_{\mathrm{ex}}$-derived mixing rates from locations in the western North Pacific for depths greater than $4000 \mathrm{~m}$ range from 0.1 to $1 \mathrm{~cm}^{2} \mathrm{yr}^{-1}$ (Moon et al., 2003; Yang et al., 1985). Sedimentation rates for these locations were found to be 0.0001 to $0.002 \mathrm{~cm} \mathrm{yr}^{-1}$. Using the offshore mixing rates as a minimum for the coastal region near Fukushima, $w$ would need to approach $0.12 \mathrm{~cm} \mathrm{yr}^{-1}$ to be considered significant. Therefore, sedimentation was considered negligible over the decades following the FDNPP release and Eq. (2) can be further simplified to (Cochran, 1985; Yang et al., 1985)

Activity $=A_{o} e^{-x \sqrt{\frac{\lambda}{D_{\mathrm{B}}}}}$. 


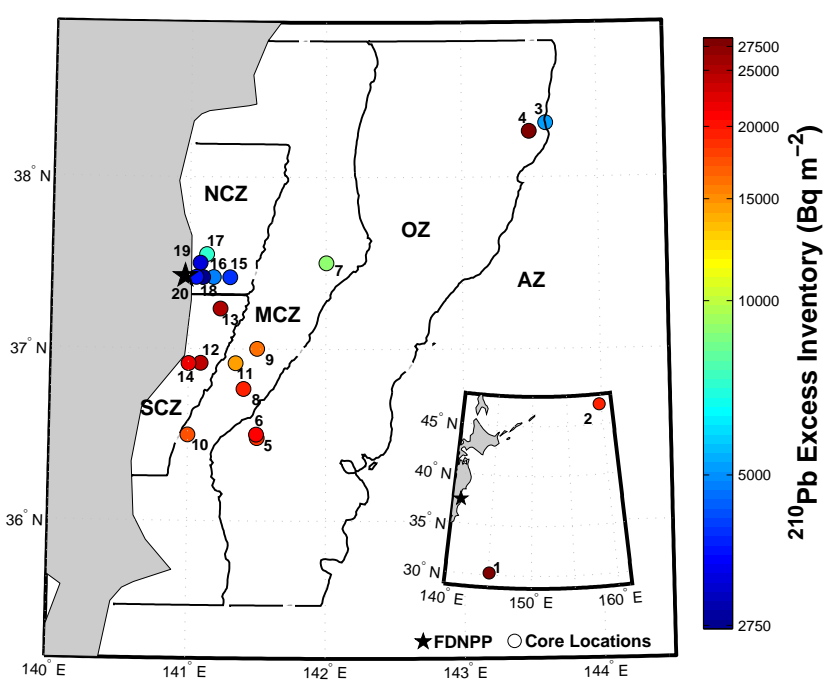

Figure 1. Core locations with ${ }^{210} \mathrm{~Pb}_{\mathrm{ex}}$ inventories. Larger map: core locations 3 to 20 and the northern coastal (NCZ), southern coastal (SCZ), mid-coastal (MCZ), offshore (OZ), and abyssal (AZ) zones. Lower right: core locations 1 and 2. Some of the reported values may underestimate total inventories at the locations where ${ }^{210} \mathrm{~Pb}_{\mathrm{ex}}$ continues to the core bottom (Fig. 2).

A dynamic, exponential regression analysis was performed on ${ }^{234} \mathrm{Th}_{\mathrm{ex}}$ and ${ }^{210} \mathrm{~Pb}_{\mathrm{ex}}$ activity $\left(\mathrm{Bq} \mathrm{kg}^{-1}\right.$ dry) profile sections of each core using Eq. (5). In practice, mixing rates are typically higher in surface sediments, and therefore ${ }^{234} \mathrm{Th}_{\mathrm{ex}}$ profiles were used to derive $D_{\mathrm{B}}$ for upper layers, when present, and ${ }^{210} \mathrm{~Pb}_{\mathrm{ex}}$ was used below. Bioturbation was assumed to be the dominate process controlling isotope distributions in the sediments, although $D_{\mathrm{B}}$ is a diffusive approximation of the combined effect of bioturbation and potential physical mixing processes.

To model the expected changes over time in ${ }^{137} \mathrm{Cs}$ profiles, we used a pulse input model and the ${ }^{234} \mathrm{Th}_{\mathrm{ex}}$ - and ${ }^{210} \mathrm{~Pb}_{\mathrm{ex}}$ derived $D_{\mathrm{B}}$ s (Cochran, 1985; Yang et al., 1985):

$$
\frac{A}{A_{o}}=e^{\frac{-x^{2}}{4 D_{\mathrm{B}} t}}
$$

where $A$ is the activity at any given depth $x, A_{\mathrm{o}}$ is the shallowest surface activity, $D_{\mathrm{B}}$ is the mixing rate, and $t$ is the time since the maximum input (6 April 2011; Buesseler et al., 2011). Keeping all other variables constant, we modeled the cesium activity profiles to determine the time needed for average cesium activities from the top $3 \mathrm{~cm}$ to decrease by $50 \%$ due to sediment mixing and, hence, the transport of the cesium deeper into the core. Therefore, we have assumed that most of the cesium input to the sediments would track cesium delivery to the coastal waters. Sediment trap data in the North Pacific show rapid transport of cesium to depth, even in deep waters, within days of the input of cesium to the surface ocean (Honda et al., 2013).

\section{Results and discussion}

\subsection{Variability between multi-core tubes}

From a single multi-corer cast, we retrieved eight separate sample tubes (R1 to R8) and analyzed each for ${ }^{210} \mathrm{~Pb}_{\mathrm{ex}}$, ${ }^{137} \mathrm{Cs}$, and ${ }^{134} \mathrm{Cs}$. Core 13 was retrieved from the same location during an additional mutli-corer cast (Fig. 1). ${ }^{137} \mathrm{Cs}$ activities in the top 0 to $5 \mathrm{~cm}$ of these subcores varied from $45 \pm 3$ to $220 \pm 20 \mathrm{~Bq} \mathrm{~kg}^{-1}$ and ${ }^{210} \mathrm{~Pb}_{\mathrm{ex}}$ from $140 \pm 10$ to $220 \pm 20 \mathrm{~Bq} \mathrm{~kg}^{-1}$ (Supplement S2). Inventories for ${ }^{137} \mathrm{Cs}$ in the top $5 \mathrm{~cm}$ were $1600 \pm 100$ to $6500 \pm 500 \mathrm{~Bq} \mathrm{~m}^{-2}$ and $5500 \pm 400$ to $7800 \pm 600 \mathrm{~Bq} \mathrm{~m}^{-2}$ for ${ }^{210} \mathrm{~Pb}_{\text {ex }}$. Inventories for core 13 for the same 0 to $5 \mathrm{~cm}$ layer were $8000 \pm 200$ and $6400 \pm 200 \mathrm{~Bq} \mathrm{~m}^{-2}$ for ${ }^{137} \mathrm{Cs}$ and ${ }^{210} \mathrm{~Pb}_{\mathrm{ex}}$, respectively. The large inventory differences for both ${ }^{137} \mathrm{Cs}$ and ${ }^{210} \mathrm{~Pb}_{\mathrm{ex}}$ indicate a high degree of variability between casts and between individual tubes from a single cast. We could not obtain a coefficient of determination $\left(\mathrm{R}^{2}\right)$ greater than 0.1 for an exponential, logarithmic, or linear regression of ${ }^{134} \mathrm{Cs}$ and ${ }^{210} \mathrm{~Pb}_{\text {ex }}$ inventories, which confirms that the factors controlling inventories at the local scale vary for the two isotopes (Supplement S3).

Although we observed large tube-to-tube differences in the cesium activities, the grain size results for each of the 8 subcores were relatively similar in magnitude (Supplement S4). D50 values ranged from 19 to $41 \mu \mathrm{m}$, percent clay from 7.3 to 12 , and percent fines from 66 to 85 . Although a study of the Irish Sea found elevated ${ }^{137} \mathrm{Cs}$ activities with increasing percentages of higher surface area particles (Poole et al., 1997), such as clays, we could not find any relationship (exponential, linear, or logarithmic) with an $R^{2}$ value of greater than 0.1 between the three grain size parameters and cesium activities or inventories at this single site (Supplement S5). ${ }^{210} \mathrm{~Pb}_{\text {ex }}$ activities showed some relationship with percent clay in the replicate cores ( $R^{2}$ values ranging from 0.34 to 0.36 ). While Kusakabe et al. (2013) posited that low bulk densities could indicate finer grain sizes and abundant organic matter content, we did not see evidence of this in the replicate cores. Although particle size characteristics do not appear to control local differences in radionuclide activities, where variations in average particle size and abundances of particle types (clays, etc.) are relatively small, they may be important over larger regional scales where mineralogical differences are greater (see Sect. 3.5).

\subsection{Zonal divisions}

Previous studies have delineated various coastal regions to estimate the total cesium delivery to the sediments near the FDNPP. Kusakabe et al. (2013) used a boundary from approximately 35.5 to $38.5^{\circ} \mathrm{N}$, while Otosaka and Kato (2014) used incremental isobaths running from 35.67 to $38.50^{\circ} \mathrm{N}$ to create eight separate zones ( 0 to $1500 \mathrm{~m}$ ). For consistency, we used 35.5 to $38.5^{\circ} \mathrm{N}$ for our northernmost and 


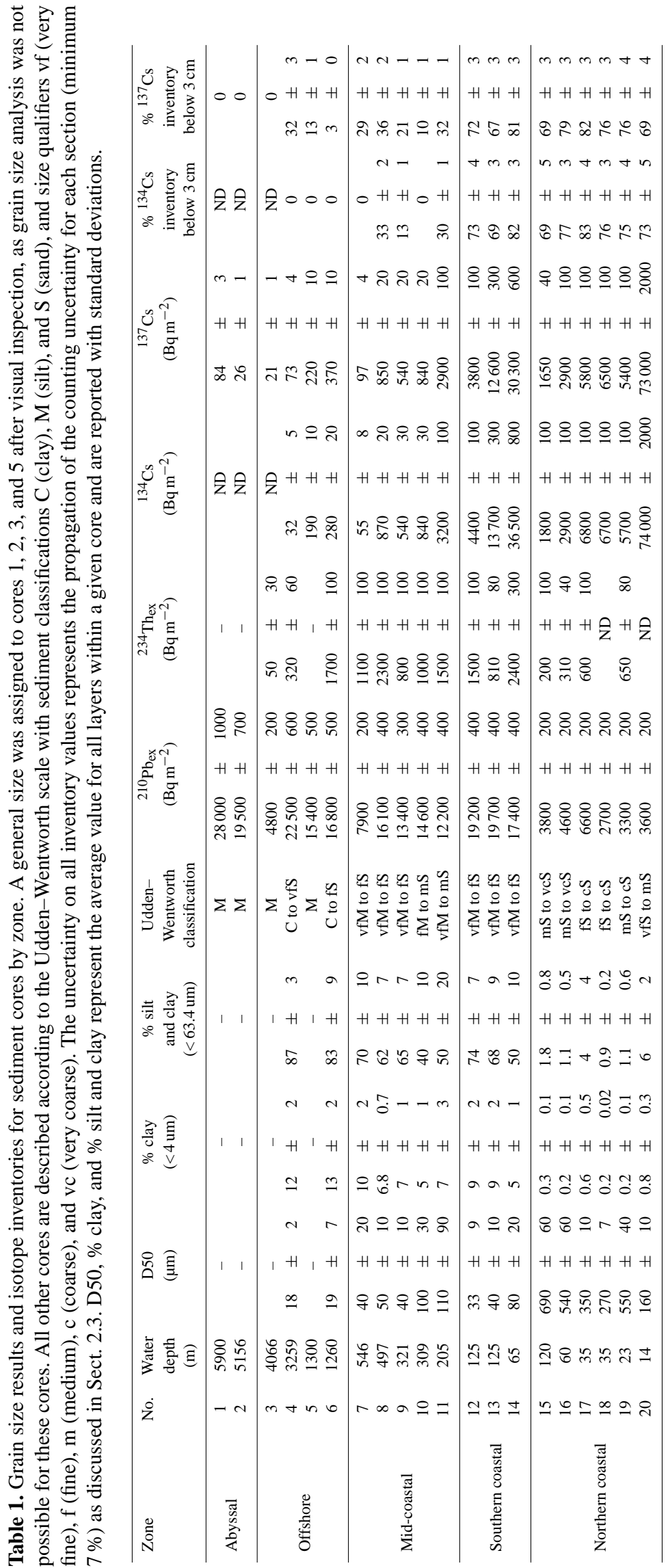


southernmost zonal boundaries and isobaths for eastern and western divisions (Fig. 1 and Table 1). We divided the sediment reservoir into five zones based on inventories, grain size, and mixing rate estimates from our 20 sediment cores (see Sect. 3.3 to 3.7). The northern coastal zone (NCZ, $n=6)$ and southern coastal zone (SCZ, $n=3$ ) are bound by the $150 \mathrm{~m}$ isobath to the east. The northern and southern boundaries of the NCZ and SCZ were shortened to 38.20 and $36.25^{\circ} \mathrm{N}$, respectively, after consideration of additional surface cores from MEXT (Kusakabe et al., 2013) (see Sect. 3.9). The mid-coastal zone (MCZ, $n=5$ ) is bound by the $800 \mathrm{~m}$ isobath to the east and the Japanese coast, NCZ, and SCZ to the west. The offshore zone $(\mathrm{OZ}, n=4)$ is bound to the west and east by the 800 and $4000 \mathrm{~m}$ isobaths, respectively. We included core $3(4066 \mathrm{~m})$ in the OZ because of its proximity to core 4 and an underrepresentation of deeper cores in this zone. The remaining cores $(n=2)$ are located in the abyssal zone (AZ). All result and calculations in the following sections will be discussed relative to these zones.

\subsection{Grain size analysis}

Two cores from the OZ and all cores from the NCZ, SCZ, and $\mathrm{MZ}$ were analyzed by layer with a Beckman Coulter counter, and the results were averaged by core (Table 1). The remaining four cores were visually assessed with a hand lens and assigned a general size class relative to the UddenWentworth classification scheme. The NCZ cores contained the lowest percent clay $(0.2$ to $0.8 \%)$ and yielded the highest D50 values, ranging from 160 to greater than $690 \mu \mathrm{m}$. These cores were composed of relatively well sorted sands, and D50 standard deviations were generally less than $10 \%$ of the D50 value. The SCZ cores contained more poorly sorted grain assemblages and could be characterized as mostly siltdominated with some fine sands. D50 values for these cores ranged from 33 to $80 \mu \mathrm{m}$, an order of magnitude lower than those observed in the NCZ, and the percent clay ranged from 5 to $9 \%$, an order of magnitude higher than those in the NCZ. The MCZ cores were fairly similar in characteristics to the SCZ cores and ranged from 5 to $10 \%$ clay and in D50 from 40 to $110 \mu \mathrm{m}$. The two OZ cores were very fine grained and had relatively similar D50 and percent clay values of approximately $18.5 \mu \mathrm{m}$ and $12.5 \%$, respectively.

The average values for D50, percent fines, and percent clay reflected wide variations in grain size from the coastal to offshore regions, although for a given core the changes in grain size between individual layers from top to bottom were generally small. We saw that, as water depth increased to $5900 \mathrm{~m}$, average grain sizes generally transitioned from coarser sands and granules $(0.5$ to $4 \mathrm{~mm})$ to very fine silts and clays $(<63 \mu \mathrm{m})$. This broad relationship did not always hold true in the nearshore, however, as the NCZ and SCZ cores differed in average grain size characteristics but not in water depth. Although a few cores showed D50 layer variations up to $220 \mu \mathrm{m}$ over $2 \mathrm{~cm}$ increments, no observable pattern ex- isted when these fluctuations were compared with changes in isotope activities. Conversely, many large layer-to-layer cesium fluctuations, like those seen in core 17 , could not be explained by changes in grain size. Despite the likelihood that some or all of the cores might contain tsunami deposits, there was no grain size evidence of fining-upward sequences in these cores, sharp layer contacts with largely differing grain sizes, or definitive indicators that would allow us to separate potential tsunami layers from sections impacted by bioirrigation, bioturbation, or local physical processes (Sakuna et al., 2012).

\subsection{Cesium activity profiles}

Average surface activities for the top $3 \mathrm{~cm}$ in the cores ranged from $2.1 \pm 0.1$ (core 2, C2) to $630 \pm 30(\mathrm{C} 20) \mathrm{Bq} \mathrm{kg}^{-1}$ dry for ${ }^{137} \mathrm{Cs}$ and from $0(\mathrm{C} 2)$ to $550 \pm 30(\mathrm{C} 20) \mathrm{Bq} \mathrm{kg}^{-1}$ dry for ${ }^{134} \mathrm{Cs}$ (Supplement S6). The AZ cores contained no detectable ${ }^{134} \mathrm{Cs}$. The average surface activities in the $\mathrm{OZ}$ ranged from 0 (C3) to $12 \pm 1$ (C6) $\mathrm{Bq} \mathrm{kg}^{-1}$ dry for ${ }^{134} \mathrm{Cs}$, while the MCZ activities ranged from $3 \pm 0.5$ (C7) to $57 \pm 2$ (C11) $\mathrm{Bq} \mathrm{kg}^{-1}$ dry for ${ }^{134} \mathrm{Cs}$. NCZ cores 15 through 19 had a similar range of average surface activities from $19 \pm 1$ (C16) to $50 \pm 2(\mathrm{C} 18) \mathrm{Bq} \mathrm{kg}^{-1}$ dry. While most surface ${ }^{134} \mathrm{Cs}$ activities in the NCZ were unexpectedly low, despite their proximity to the FDNPP, core 20, located within $3 \mathrm{~km}$ of the FDNPP, had the highest average surface activity overall. With the exception of this core, the cores in the SCZ had the greatest average surface activities of all zones, with ${ }^{134} \mathrm{Cs}$ values ranging from $170 \pm 10(\mathrm{C} 13)$ to $230 \pm 10(\mathrm{C} 14) \mathrm{Bq} \mathrm{kg}^{-1}$.

Cesium profiles varied strongly in shape and penetration depth between zones (Fig. 2). Cores in the $\mathrm{AZ}$ and $\mathrm{OZ}$ had either fallout-only profiles with no ${ }^{134} \mathrm{Cs}$ and very low ${ }^{137} \mathrm{Cs}$ or rapidly decreasing ${ }^{134} \mathrm{Cs}$ and ${ }^{137} \mathrm{Cs}$ activities with depth. FDNPP-derived cesium penetration was limited to the top $3 \mathrm{~cm}$ in these zones. The MCZ cores generally showed similar exponentially decreasing cesium activities with depth with the exception of core 11, which showed a pronounced peak between 1 and $4 \mathrm{~cm}$. Generally, the penetration depth of ${ }^{134} \mathrm{Cs}$ was deeper here than in the $\mathrm{AZ}$ and $\mathrm{OZ}$ cores. The SCZ cores maintained substantially higher cesium activities from 0 to $8 \mathrm{~cm}$ relative to most other cores, and we observed both exponentially decreasing activities and vertical profiles below $8 \mathrm{~cm} .{ }^{134} \mathrm{Cs}$ was found to a depth of $18 \mathrm{~cm}$ in core 12 and over the full length of cores $13(19 \mathrm{~cm})$ and $14(16 \mathrm{~cm})$ in the SCZ. While the NCZ cores had similar surface activities to those in the MCZ, most cores in this zone showed distinctive semi-vertical profiles from the surface to the coring depths. Core 17 was the only exception and the only core to exhibit large fluctuations in activity with depth. Because we observed ${ }^{134} \mathrm{Cs}$ at all core bottoms and without decreasing trends in most of the NCZ cores, we could not estimate maximum penetration depths. 


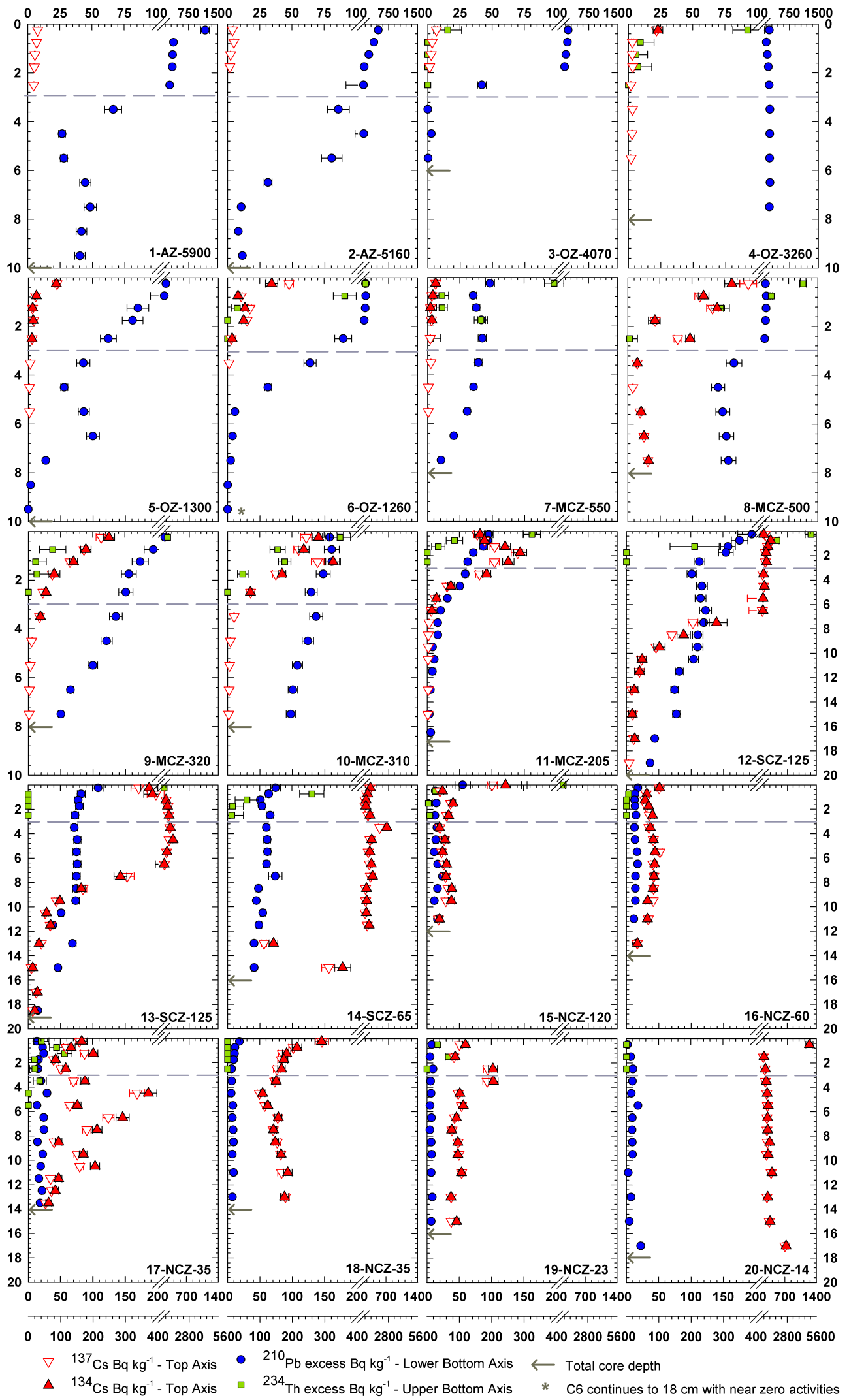

- _ $3 \mathrm{~cm}$ depth for MEXT comparison (\#- XXX -\#) Core Number - Zone - Water Depth

Figure 2. Sediment activity profiles in $\mathrm{Bq} \mathrm{kg}^{-1}$ for ${ }^{134} \mathrm{Cs},{ }^{137} \mathrm{Cs},{ }^{210} \mathrm{~Pb}_{\mathrm{ex}}$, and ${ }^{234} \mathrm{Th}_{\mathrm{ex}}$. 


\subsection{Cesium inventories}

Total ${ }^{134} \mathrm{Cs}$ and ${ }^{137} \mathrm{Cs}$ inventories ranged from 0 (C1) to $74000 \pm 2000 \quad(\mathrm{C} 20) \mathrm{Bq} \mathrm{m}^{-2}$ and $21 \pm 1 \quad$ (C3) to $73000 \pm 2000(\mathrm{C} 20) \mathrm{Bq} \mathrm{m}^{-2}$, respectively (Table 1). Our inventory range for ${ }^{137} \mathrm{Cs}$ was almost 4 times larger than those reported in Kusakabe et al. (2013; approximately 100 to $18,000 \mathrm{~Bq} \mathrm{~m}^{-2}$ ) and Otosaka and Kato (2014; approximately 100 to $19100 \mathrm{~Bq} \mathrm{~m}^{-2}$ ). This could be attributed to both greater core lengths and larger total area sampled, including the $30 \mathrm{~km}$ zone around the FDNPP. Cesium inventories generally decreased with water depth. AZ and OZ inventories were less than $400 \mathrm{~Bq} \mathrm{~m}^{-2}$ for both isotopes, and the MCZ contained only one core inventory above $1000 \mathrm{~Bq} \mathrm{~m}^{-2}$. Excluding core 20, we observed cesium inventories on the order of 1500 to $7000 \mathrm{~Bq} \mathrm{~m}^{-2}$ in the NCZ and 4000 to $36500 \mathrm{~Bq} \mathrm{~m}^{-2}$ in the SCZ. The cesium inventories for core 20 were double that of the next-highest value and reflected a proximity to the FDNPP. Pre-accident cores from the broader western North Pacific have been reported to contain tens to thousands of $\mathrm{Bq} \mathrm{m}^{-2}$ of ${ }^{137} \mathrm{Cs}$ (Moon et al., 2003; Lee et al., 2005). Assuming a weapons-testing delivery of $2500 \mathrm{~Bq} \mathrm{~m}^{-2}$ for $30^{\circ}$ to $40^{\circ} \mathrm{N}$ (Bowen et al., 1980) and 1-5\% delivery to the sediments, we expect an average sediment inventory of ${ }^{137} \mathrm{Cs}$ less than $50 \mathrm{~Bq} \mathrm{~m}^{-2}$ prior to Fukushima. We observed inventories consistent with the presence of substantial weapons-testing fallout in the $\mathrm{AZ}$ and $\mathrm{OZ}$ cores with inventory ratios for ${ }^{134} \mathrm{Cs} /{ }^{137} \mathrm{Cs}$ of 0 to 0.86 . Larger inventories and ${ }^{134} \mathrm{Cs} /{ }^{137} \mathrm{Cs}$ ratios of $\sim 1$ in most of the MCZ, NCZ, and SCZ cores suggested negligible contributions from weaponstesting ${ }^{137} \mathrm{Cs}$, relative to the larger and more recent FDNPP source.

Since many prior studies have focused on the 0 to $3 \mathrm{~cm}$ surface layer, we also calculated the percentage of total inventory that lie below $3 \mathrm{~cm}$ within each of our cores (Table 1). Percentages generally increased with shallower water depths. We observed $75 \pm 6$ and $75 \pm 5 \%$ for ${ }^{134} \mathrm{Cs}$ and $73 \pm 7$ and $75 \pm 5 \%$ for ${ }^{137} \mathrm{Cs}$ (mean $\pm \mathrm{SD}$ ) below $3 \mathrm{~cm}$ as a fraction of the total inventory in the NCZ and SCZ, respectively. In the MCZ, the percentage of total inventory below $3 \mathrm{~cm}$ was highly variable, ranging from 0 (C7 and $\mathrm{C} 10)$ to $33 \%(\mathrm{C} 8)$ for ${ }^{134} \mathrm{Cs}$ and from $10(\mathrm{C} 10)$ to $36 \%(\mathrm{C} 8)$ for ${ }^{137} \mathrm{Cs}$. The average inventory below $3 \mathrm{~cm}$ in the MCZ cores attributed to Fukushima $\left({ }^{134} \mathrm{Cs}\right)$ was $15 \pm 16 \%$, which agreed closely with the Otosaka and Kato (2014) ${ }^{134} \mathrm{Cs}$ average of $19 \%$ from core locations within the MCZ. When we combined the two data sets for the MCZ $(n=15)$ the average inventory below $3 \mathrm{~cm}$ was $18 \pm 16 \%$. In the $\mathrm{OZ}$ we saw no ${ }^{134} \mathrm{Cs}$ below $3 \mathrm{~cm}$ in any of the cores and a range of 0 (C3) to $32 \%$ (C4) for ${ }^{137} \mathrm{Cs}$. We did not observe any detectable amount of either isotope below $3 \mathrm{~cm}$ in the $\mathrm{AZ}$.

The core inventories from this study reflect changes in three main factors: distance from the FDNPP, water depth, and grain size. Proximity impacted core 20, located within $3 \mathrm{~km}$ of the FDNPP (Fig. 3a). Figure 3a, shows a general de-

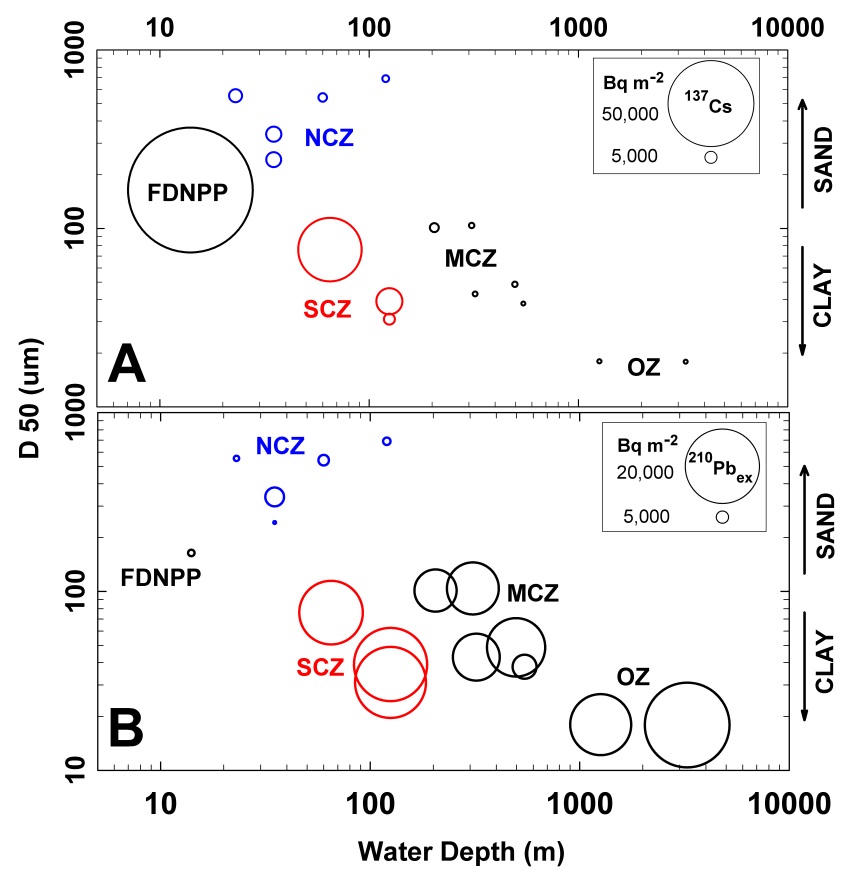

Figure 3. ${ }^{137} \mathrm{Cs}$ and ${ }^{210} \mathrm{~Pb}_{\mathrm{ex}}$ inventories relative to water depth and D50. Grain size distribution is shown for 16 of the 20 cores, including all of the NCZ, SCZ, and MCZ cores. Isotope inventories for ${ }^{134} \mathrm{Cs}$ (a) and ${ }^{210} \mathrm{~Pb}_{\mathrm{ex}}$ (b) show general depth trends with prominent grain size effects in the NCZ and SCZ.

crease in cesium inventories with increasing distance from the FDNPP and water depth, despite cesium inventories for cores 1 to 19 showing little to no statistical relationship to proximity or water depth (exponential regression $R^{2}$ values $<0.25)$. Grain size was a controlling factor in the nearshore NCZ and SCZ, where cores were sampled from similar water depth ranges and yet contained widely varying inventories (Table 1, Fig. 3a). Although no trend was observed in our replicate core tubes between grain size and cesium activities, the larger differences in grain size between the SCZ and NCZ (D50s from $\sim 30$ to $700 \mu \mathrm{m}$ ) did correspond to changes in total ${ }^{137} \mathrm{Cs}$ inventories. The $\mathrm{NCZ}$ and SCZ grain size trends mimic those observed in the Irish Sea, where an estimated $41 \mathrm{PBq}$ of cesium released over $40 \mathrm{yr}$ has been preferentially incorporated into an area known as the Sellafield mud patch (Poole et al., 1997). In summary, proximity dominated within the $3 \mathrm{~km}$ zone of FDNPP, despite the high sand content of core 20 (D50 of $160 \mu \mathrm{m}$, percent sand $\sim 94 \%$ ); grain size was the most important difference between the NCZ and SCZ; and water depth (higher particle fluxes are generally observed over more productive coastal waters) may have contributed to cesium variability in locations such as the MCZ and OZ, where water column activities were relatively low. 


\section{6 ${ }^{210} \mathrm{~Pb}_{\mathrm{ex}}$ and ${ }^{234} \mathrm{Th}_{\mathrm{ex}}$ activities and inventories}

${ }^{210} \mathrm{~Pb}_{\text {ex }}$ surface activities ( 0 to $3 \mathrm{~cm}$ average) ranged from $12 \pm 3$ (C20) to $1900 \pm 100(\mathrm{C} 1) \mathrm{Bq} \mathrm{kg}^{-1}$ and generally increased with water depth, as expected, due to the increased input from water column scavenging (Supplement S6, Figs. 1 and 2). ${ }^{210} \mathrm{~Pb}_{\mathrm{ex}}$ activities were lowest in the $\mathrm{NCZ}$ and highest in the $\mathrm{AZ}$. Intrazonal ${ }^{210} \mathrm{~Pb}_{\mathrm{ex}}$ activity ranges were smaller than for cesium. Similar to the vertical cesium activity profiles, ${ }^{210} \mathrm{~Pb}_{\mathrm{ex}}$ activities remained relatively constant with depth in the NCZ. In the other zones, activities generally decreased with core depth but also exhibited a variety of profile shapes. Generally, the termination of ${ }^{210} \mathrm{~Pb}_{\mathrm{ex}}$, the depth where all ${ }^{210} \mathrm{~Pb}$ is supported, was not attained within our sampling depths, with the exception of cores 3 and 6 (Fig. 2).

${ }^{210} \mathrm{~Pb}_{\mathrm{ex}}$ inventories, ranging from $2700 \pm 200$ (C18) to $28000 \pm 1000(\mathrm{C} 1) \mathrm{Bq} \mathrm{m}^{-2}$, reflect changes in grain size, water depth, and local processes - the factors that also impacted cesium inventories (Table 1, Figs. 1 and 3b). ${ }^{210} \mathrm{~Pb}_{\mathrm{ex}}$ inventories generally increased with water depth as expected from scavenging. The NCZ values were slightly lower than anticipated (average inventory of $4000 \pm 1000 \mathrm{~Bq} \mathrm{~m}^{-2}$ ) based on our expected atmospheric inventory calculation of $6400 \mathrm{~Bq} \mathrm{~m}^{-2}$, and the $\mathrm{SCZ}$ values were more than twice as high as expected (average inventory $20000 \pm 10000 \mathrm{~Bq} \mathrm{~m}^{-2}$ ). The SCZ is therefore a deposition center, receiving additional particles via horizontal transport. These trends are supported by the prevalence of sands in the NCZ cores and higher percentages of fines in the SCZ cores, similar to what has been observed with cesium inventories (He and Walling, 1996). An exponential regression of ${ }^{210} \mathrm{~Pb}_{\mathrm{ex}}$ inventories versus percent clay in the $\mathrm{NCZ}$ and SCZ indicated a strong relationship $\left(R^{2}>0.9\right)$ between grain size and inventories. The MCZ, OZ, and AZ core inventories of ${ }^{210} \mathrm{~Pb}_{\text {ex }}$ were generally 1 to 4 times higher than atmospheric delivery. This finding is similar to along the shelf and slope of the northeastern USA (Buesseler et al., 1985/1986) and can be attributed to both scavenging within the water column, which is higher with increasing water depth, and horizontal transport and faster scavenging rates over boundary sediments in general. Evidence of boundary scavenging of ${ }^{210} \mathrm{~Pb}$ has been shown for the western North Pacific by Cochran et al. (1990) based upon an analysis of deep sediment cores and the expected inventories from water column scavenging and atmospheric sources.

Of the 17 cores that were analyzed rapidly enough to measure ${ }^{234} \mathrm{Th}_{\mathrm{ex}}, 15$ contained ${ }^{234} \mathrm{Th}_{\mathrm{ex}}$ activities ranging from $17 \pm 3$ (C19) to $1300 \pm 100(\mathrm{C} 12) \mathrm{Bq} \mathrm{kg}^{-1}$ in the top 0 to $0.5 \mathrm{~cm}$. Surface $(0$ to $3 \mathrm{~cm}){ }^{234} \mathrm{Th}_{\mathrm{ex}}$ inventories peaked at $2400 \pm 300(\mathrm{C} 14) \mathrm{Bq} \mathrm{m}^{-2}$ in the SCZ. Most cores showed classic exponential ${ }^{234} \mathrm{Th}_{\text {ex }}$ profile shapes with higher values at the surface that dropped to near-zero excess values within 1 to $3 \mathrm{~cm}$. Although the lowest ${ }^{234} \mathrm{Th}_{\mathrm{ex}}$ inventories were found in the $\mathrm{OZ}$ and $\mathrm{NCZ}$ and the highest were generally located in the SCZ and MCZ, intrazonal variability was

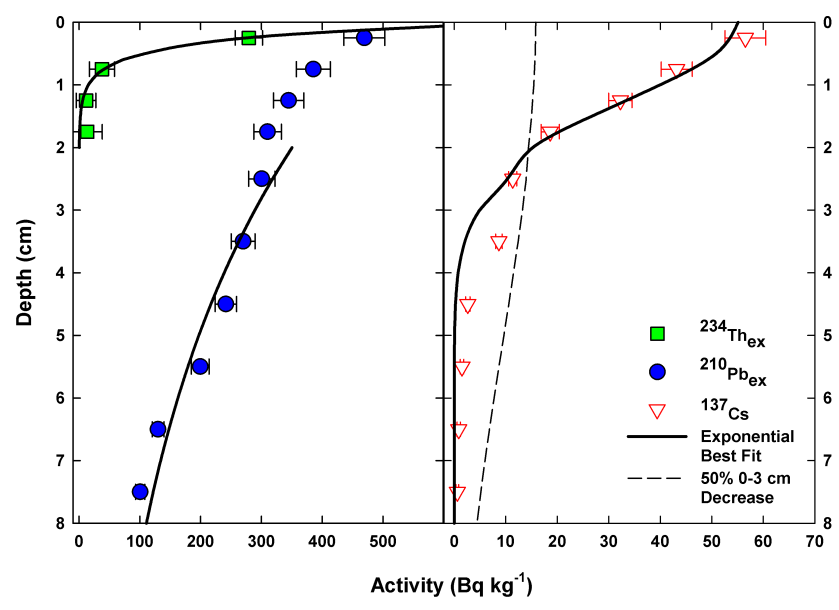

Figure 4. Example model best-fit regressions for ${ }^{210} \mathrm{~Pb}_{\mathrm{ex}},{ }^{234} \mathrm{Th}_{\mathrm{ex}}$, and ${ }^{137} \mathrm{Cs}$ for core 9. Mixing rates derived from the ${ }^{210} \mathrm{~Pb}_{\mathrm{ex}}$. ${ }^{234} \mathrm{Th}_{\mathrm{ex}}$ profiles in the left panel were used in the cesium pulse model for the right panel. In general, the model similarly fit the profiles from the MCZ, OZ, and AZ. Model fits for the SCZ and NCZ were less successful due to almost vertical profiles for some cores.

high, and more often than not inventories did not decrease with increasing depth.

\section{$4 \quad D_{B}$ estimates}

Since all of the cores showed evidence of sediment mixing, we estimated local mixing rates using ${ }^{234} \mathrm{Th}_{\mathrm{ex}}$ and ${ }^{210} \mathrm{~Pb}_{\mathrm{ex}}$ activity profiles and a steady-state diffusive mixing model (Eqs. 2 and 5; see Fig. 4 for example profile). Mixing rates in the $\mathrm{MCZ}, \mathrm{OZ}$, and $\mathrm{AZ}$ ranged from 0.7 (C9) to 9.6 (C10) $\mathrm{cm}^{2} \mathrm{yr}^{-1}$ for ${ }^{234} \mathrm{Th}_{\mathrm{ex}}$-derived estimates and from 0.06 (C1) to $3.7(\mathrm{C} 10) \mathrm{cm}^{2} \mathrm{yr}^{-1}$ for ${ }^{210} \mathrm{~Pb}_{\mathrm{ex}}$-derived estimates (Table 2). At a given location, ${ }^{234} \mathrm{Th}_{\mathrm{ex}}$-derived estimates were generally higher as they reflect processes occurring in the uppermost active sediment layers (Aller and Cochran, 1976). Rates in the SCZ and NCZ suggested intense mixing, with full core ${ }^{210} \mathrm{~Pb}_{\mathrm{ex}}$-derived estimates starting at $11 \mathrm{~cm}^{2} \mathrm{yr}^{-1}$ and the majority of rates being unquantifiable due to the vertical ${ }^{210} \mathrm{~Pb}_{\mathrm{ex}}$ profiles. The wide range in rates was not unexpected with cores from diverse sedimentary environments and water depths. While ${ }^{234} \mathrm{Th}_{\mathrm{ex}}$-derived mixing rates were not correlated with water depth $\left(R^{2}<0.1\right)$, we observed an exponentially decreasing trend in ${ }^{210} \mathrm{~Pb}_{\mathrm{ex}}$-derived mixing rates with water depth $\left(R^{2}=0.96\right)$, as observed in other coastal regions where biomass, species diversity, and bioturbation decrease with depth (Henderson et al., 1999; Joydas and Damodaran, 2009).

Although ${ }^{234} \mathrm{Th}_{\mathrm{ex}}$ was absent from some of the deepest AZ, OZ, and MCZ cores, we succeeded in obtaining ${ }^{210} \mathrm{~Pb}_{\mathrm{ex}}$ and ${ }^{234} \mathrm{Th}_{\mathrm{ex}}$ mixing rates for most cores located in these zones. In general, the activity profiles exponentially decreased with depth (Figs. 2 and 4), and the AZ and OZ 
Table 2. Mixing rates and model results for sediment cores. Analysis of samples from cores marked NP was not possible because no ${ }^{234} \mathrm{Th}_{\mathrm{ex}}$ was present or because of insufficient trends in ${ }^{234} \mathrm{Th}_{\mathrm{ex}}$ or ${ }^{210} \mathrm{~Pb}_{\mathrm{ex}}$. Due to the limited number of surface ${ }^{234} \mathrm{Th}_{\mathrm{ex}}$ points, the uncertainties reported represent the higher of the standard uncertainty of the model fit for variable $D_{\mathrm{B}}$ or $25 \%$ of $D_{\mathrm{B}}$. The last column contains values representing the time in years since the Fukushima maximum for surface concentrations $(0-3 \mathrm{~cm})$ to decrease by $50 \%$ via mixing (modeled). The uncertainties reflect the mixing rate(s) used in the model.

\begin{tabular}{|c|c|c|c|c|c|c|}
\hline Zone & No. & $\begin{array}{l}{ }^{234} \mathrm{Th}_{\mathrm{ex}^{-}} \\
\text {derived } D_{\mathrm{B}} \\
\left(\mathrm{cm}^{2} \mathrm{yr}^{-1}\right)\end{array}$ & $\begin{array}{l}\text { Depths } \\
\text { used } \\
(\mathrm{cm})\end{array}$ & $\begin{array}{c}{ }^{210} \mathrm{~Pb}_{\mathrm{ex}^{-}} \\
\text {derived } D_{\mathrm{B}} \\
\left(\mathrm{cm}^{2} \mathrm{yr}^{-1}\right)\end{array}$ & $\begin{array}{l}\text { Depths } \\
\text { used } \\
(\mathrm{cm})\end{array}$ & $\begin{array}{c}\text { Estimated years until } \\
50 \% \text { decrease in } \\
\text { surface cesium }(\mathrm{m})\end{array}$ \\
\hline \multirow[t]{2}{*}{ Abyssal } & 1 & NP & & $0.06 \pm 0.02$ & $1.5-5$ & $26 \pm 2$ \\
\hline & 2 & NP & & $0.6 \pm 0.2$ & $1.5-9$ & $10 \pm 2$ \\
\hline \multirow[t]{4}{*}{ Offshore } & 3 & NP & & $0.07 \pm 0.02$ & $0.5-3$ & $26 \pm 2$ \\
\hline & 4 & $0.8 \pm 0.2$ & $0-2$ & NP & & $6 \pm 2$ \\
\hline & 5 & NP & & $0.5 \pm 0.1$ & $1.5-9$ & $11 \pm 2$ \\
\hline & 6 & $5.5 \pm 4$ & $0-1.5$ & $0.09 \pm 0.02$ & $2-8$ & $24 \pm 1$ \\
\hline \multirow[t]{5}{*}{ Mid-coastal } & 7 & $0.9 \pm 0.7$ & $0-3$ & $0.8 \pm 0.2$ & $2-8$ & $5 \pm 2$ \\
\hline & 8 & $2.4 \pm 0.6$ & $0-2$ & $0.3 \pm 0.1$ & $1.5-5$ & $15 \pm 1$ \\
\hline & 9 & $0.7 \pm 0.2$ & $0-2$ & $0.8 \pm 0.1$ & $2-8$ & $8 \pm 1$ \\
\hline & 10 & $9.6 \pm 3$ & $0-2$ & $3.7 \pm 0.4$ & $3-8$ & $2 \pm 1$ \\
\hline & 11 & $1.6 \pm 0.4$ & $0-1.5$ & $0.6 \pm 0.1$ & $1.5-10$ & $10 \pm 1$ \\
\hline \multirow[t]{3}{*}{ Southern coastal } & 12 & $2.7 \pm 0.7$ & $0-1.5$ & $12 \pm 2$ & $1.5-20$ & $0.8 \pm 0.2$ \\
\hline & 13 & NP & & $11 \pm 2$ & $0-19$ & $0.9 \pm 0.2$ \\
\hline & 14 & $2.5 \pm 0.6$ & $0-2$ & $22 \pm 6$ & $2-16$ & $0.4 \pm 0.2$ \\
\hline \multirow[t]{6}{*}{ Northern coastal } & 15 & $0.3 \pm 0.1$ & $0-2$ & NP & & $14 \pm 2$ \\
\hline & 16 & $0.4 \pm 0.1$ & $0-2$ & NP & & $12 \pm 4$ \\
\hline & 17 & NP & & NP & & NP \\
\hline & 18 & NP & & NP & & NP \\
\hline & 19 & NP & & NP & & NP \\
\hline & 20 & NP & & NP & & NP \\
\hline
\end{tabular}

${ }^{210} \mathrm{~Pb}_{\mathrm{ex}}$-derived mixing rates agreed well with the observed historical rates from this region of 0.1 to $1 \mathrm{~cm}^{2} \mathrm{yr}^{-1}$ (Moon et al., 2003; Yang et al., 1985). Cores from the shallowest regions (NCZ and SCZ) were the most difficult to fit with the simplified sediment mixing-only model (Eq. 5). The SCZ cores generally contained three layers of mixing: a 1 to $3 \mathrm{~cm}$ moderately fast mixing zone at the surface, a 5 to $10 \mathrm{~cm}$ rapid mixing layer with an almost vertical profile, and a deep mixing zone with similar mixing rates to the surface layers. Equation (5) could not be used at all to derive ${ }^{210} \mathrm{~Pb}_{\mathrm{ex}}$ mixing rates for any of the NCZ cores due to the almost vertical activity profiles throughout. In these instances, the observed profile trends could have resulted from extremely rapid mixing or from resuspension and deposition resulting from a tsunami or storm-related event, although we did not see evidence of individual storm deposits in the grain size analysis (see Sect. 3.3).

\subsection{Cesium modeling of changes in surface activities}

To explore how quickly sediment mixing could potentially reduce surface $(0$ to $3 \mathrm{~cm})$ cesium activities over time, we calculated the change in surface cesium activity, assuming a pulse-like input (Eq. 6). The ${ }^{234} \mathrm{Th}_{\mathrm{ex}}$-derived mixing rate was used for the depths specified in Table 2, and the corresponding ${ }^{210} \mathrm{~Pb}_{\mathrm{ex}}$-derived mixing rate was used for the rest of the core. If no rate existed for one of the isotopes, the mixing rate from the other was applied to all depths. The decay of ${ }^{137} \mathrm{Cs}$, although small over 5 to $10 \mathrm{yr}$, was subtracted from the profile activities after all other calculations to show changes due to mixing only. In general, the measured cesium activity profiles for the top $3 \mathrm{~cm}$ matched fairly well with the pulse model output for our sampling dates using the local bioturbation rate. Below $3 \mathrm{~cm}$, the model generally followed the AZ, OZ, and MCZ measured cesium profiles (see Fig. 4 for example profile) and underestimated the $\mathrm{NCZ}$ and $\mathrm{SCZ}$ profiles.

The time until the surface $(0$ to $3 \mathrm{~cm})$ activities decreased by $50 \%$ ranged from $0.4(\mathrm{C} 14)$ to $26(\mathrm{C} 1$ and $\mathrm{C} 3)$ years for the 20 cores (Table 2). The SCZ times ranged from 0.4 (C14) to 0.9 (C13) years and the MCZ times from 2 (C10) to 15 (C8) years. We could not model any of the cesium profiles in the $\mathrm{NCZ}$ using ${ }^{210} \mathrm{~Pb}_{\text {ex }}$ mixing rates, and the two with ${ }^{234} \mathrm{Th}_{\text {ex }}$ mixing rates yielded estimates from $12(\mathrm{C} 16)$ to 14 (C15) years, which seemed unrealistically long when considering the water depth and shape of the vertical profiles. 
The longest time period for decrease will occur in the slowmixing $\mathrm{OZ}$ and $\mathrm{AZ}$ regions, whose $50 \%$ reduction time varied from $6(\mathrm{C} 4)$ to $26(\mathrm{C} 1$ and $\mathrm{C} 3)$ years.

\subsection{Total seafloor cesium inventory calculations}

We estimated that the marine sediments contained approximately $100 \pm 50 \mathrm{TBq}$ of ${ }^{137} \mathrm{Cs}$ for an area of $55000 \mathrm{~km}^{2}$ (Tables $3 \mathrm{a}$ and $\mathrm{b}$ ). The final totals for each zone were calculated by finding the mean inventory of all cores within that zone and multiplying by the area of the zone. Zonal and final totals are reported with standard deviations for data set (1), using cores from this study only, in Table 3b. Inventory calculations should represent underestimates of actual reservoir totals because the profiles in the highest inventory zones, the NCZ and SCZ, still showed Fukushima ${ }^{134} \mathrm{Cs}$ in their deepest sample layers. We did not calculate an inventory value for the AZ, which is extensive but should not significantly contribute to overall inventories due to low cesium activities. Furthermore, the cores from the greatest water depths, 1 and 2, did not contain Fukushima ${ }^{134} \mathrm{Cs}$, although it has been detected in sediments as far offshore as the Japan Trench (water depth of > $7000 \mathrm{~m}$; Oguri et al., 2013).

To improve our inventory estimate, we added cores recovered in February 2012 by MEXT (Kusakabe et al., 2013) and from August to November 2011 reported in Otosaka and Kato (2014) (OTKA). These provided an additional 50 locations, referred to as data sets (3) and (2), respectively. The inventories of the shorter sediment cores were increased using the average percent ${ }^{134} \mathrm{Cs}$ inventory below 3 and $10 \mathrm{~cm}$ determined for each zone when applicable (see Sect. 3.5). Cesium activity and inventory values from the MEXT and OTKA data sets were not changed if the depth sampled was sufficient to capture the full extent of cesium penetration. The additional locations did not impact the sediment inventory estimate, now $100 \pm 40 \mathrm{TBq}$, and did not substantially change the distribution of cesium between zones (Tables $3 \mathrm{a}$ and $b)$.

In a final effort to further improve our inventory estimates, we utilized all earlier sampling dates from the 30 MEXT locations in Fig. 5 and calculated a total sediment reservoir estimate of $130 \pm 60 \mathrm{TBq}(n=199$, Table $3 \mathrm{~b})$. These locations were sampled at approximately monthly intervals starting June 2011 and are referred to as data set (4). As we have observed, the range in local variability can be almost as high as that on the zonal or regional scale (Kusakabe et al., 2013; Thornton et al., 2013), so additional sampling at one site should not bias the zonal averages towards these repeated locations. However, because of the much earlier sampling dates for the MEXT cores relative to our last date in September 2013 and the $3 \mathrm{~cm}$ sampling length, we considered the sensitivity of our inventory estimate to mixing, which could transport cesium to deeper layers between sampling events. Using Eq. (6) and the estimates of mixing rates, we determined the average percent of cesium below $3 \mathrm{~cm}$ for each zone in June

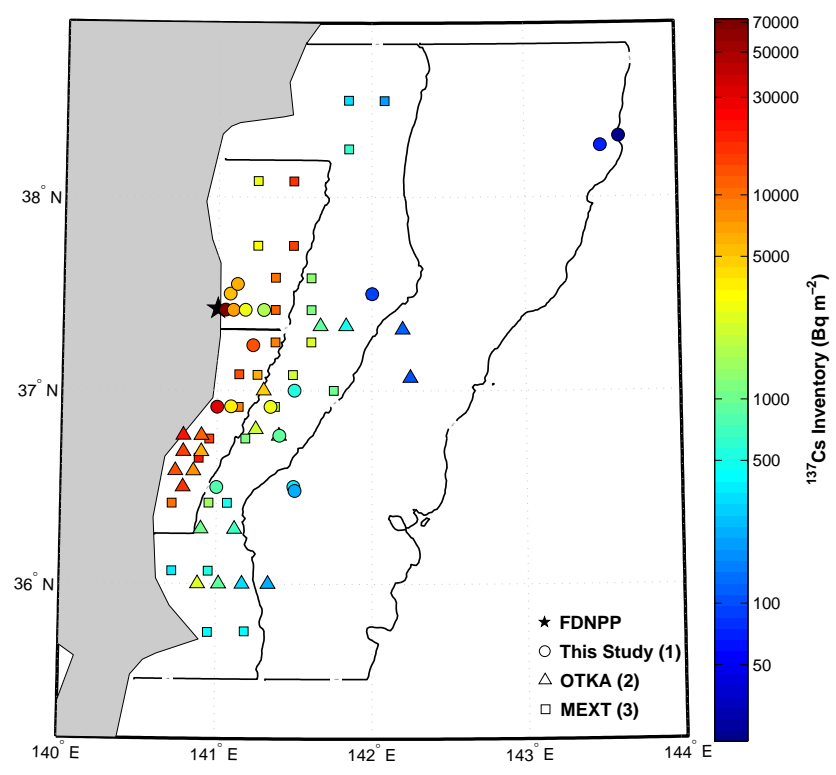

Figure 5. A compilation of sediment ${ }^{137} \mathrm{Cs}$ inventories from the coastal region around Fukushima, Japan. Core inventories from this study are shown as measured from May 2012 to September 2013. MEXT cores from February 2012 (Kusakabe et al., 2013) and OTKA samples from August through November of 2011 (Otosaka and Kato, 2014) were adjusted as necessary by zone to include estimated inventories deeper than 3 and $10 \mathrm{~cm}$, respectively (Sect. 3.5).

2011 and used these smaller percentages instead of those in Sect. 3.5 to adjust the MEXT data. After this adjustment, the total inventory estimate decreased slightly to $100 \pm 60 \mathrm{TBq}$.

The three approximation methods all resulted in similar total ${ }^{137} \mathrm{Cs}$ sediment inventories, ranging from 100 to $130 \mathrm{TBq}$ (Tables $3 \mathrm{a}$ and $\mathrm{b}$ ). The OZ comprised more than half the entire area but consistently totaled only 4 to $6 \%$ of the ${ }^{137} \mathrm{Cs}$ sediment inventory. The MCZ represents $30 \%$ of regional surface area and contained between 15 and $18 \%$ of the total ${ }^{137} \mathrm{Cs}$. The NCZ was split into two subzones to account for the extremely high inventory observed within the $3 \mathrm{~km}$ radius of the FDNPP. Based on Thornton et al.'s continuous tow data, the area immediately around the nuclear facility $(\sim 3 \mathrm{~km})$ showed the largest number of high ${ }^{137} \mathrm{Cs}$ $\mathrm{Bq} \mathrm{kg}^{-1}$ anomalies relative to adjacent sediments (Thornton et al., 2013). Core 20 confirmed that this region was distinctly higher in activity and warranted its own subzone, so as not to skew the NCZ inventory average. The $3 \mathrm{~km}$ subzone adjacent to the FDNPP accounted for approximately $1 \%$ of the total inventory. Although this inventory could change with the addition of new and deeper cores, it would not change the total regional inventory more than a few terabecquerels, even assuming a mixed layer depth of $50 \mathrm{~cm}$ (cesium penetration to $50 \mathrm{~cm}$; Walbran, 1996), because the $3 \mathrm{~km}$ subzone only comprises $0.03 \%$ of the total area. The NCZ and the SCZ, on the other hand, contributed the most cesium by far (over $70 \%$ ), 
Table 3a. Zonal statistics used for inventory estimates. Cores from group (1) are from this study only. Samples in group (2) were taken from Otasaka and Kato (2014; OTKA). Group (3) includes MEXT cores from February 2012 only, and group (4) contains MEXT cores from (3) plus additional cores from the end of June 2011 through February 2012 (Kusakabe et al., 2013).

\begin{tabular}{|c|c|c|c|c|c|c|c|c|}
\hline & \multirow{3}{*}{ Zone } & \multirow{3}{*}{$\begin{array}{c}\text { Depth ranges } \\
\text { (m) }\end{array}$} & \multirow{3}{*}{$\begin{array}{c}\text { Area } \\
\left(\mathrm{km}^{2}\right)\end{array}$} & \multirow{3}{*}{$\begin{array}{l}\% \text { of } \\
\text { area }\end{array}$} & \multicolumn{4}{|c|}{ No. of sample points } \\
\hline & & & & & (1) & (2) & (3) & $(4)$ \\
\hline & & & & & This study & OTKA & MEXT & MEXT \\
\hline $\mathrm{OZ}$ & & $800-4000$ & 30832 & $56 \%$ & 4 & 3 & 0 & 0 \\
\hline $\mathrm{MCZ}$ & & $150-800$ & 16087 & $29 \%$ & 5 & 10 & 17 & 77 \\
\hline SCZ & & $0-150$ & 3309 & $6 \%$ & 3 & 7 & 7 & 43 \\
\hline \multirow{2}{*}{$\mathrm{NCZ}$} & Greater area & $0-150$ & 4731 & $9 \%$ & 5 & 0 & 6 & 41 \\
\hline & $3 \mathrm{~km}$ radius & & 14 & $0.03 \%$ & 1 & 0 & 0 & 0 \\
\hline & Total & $0-4000$ & \multicolumn{2}{|c|}{$54973 \mathrm{~km}^{2}$} & 18 & 20 & 30 & 161 \\
\hline
\end{tabular}

Table 3b. Total ${ }^{137} \mathrm{Cs}$ inventory results by zone and data sets used. Estimates of total marine sediment ${ }^{137}$ Cs inventories were found for this study only $(n=18)$ and by including data sets from Otasaka and Kato (2014) and Kusakabe et al. (2013) that were adjusted by zone based on calculated average percent inventories observed below 3 to $10 \mathrm{~cm}$. See Table 3 a for group numbers.

\begin{tabular}{|c|c|c|c|c|c|c|c|c|c|c|}
\hline & \multirow[b]{2}{*}{ Zone } & \multicolumn{3}{|c|}{ This study (1) } & \multicolumn{3}{|c|}{ (1) \& (2) \& (3) } & \multicolumn{3}{|c|}{ (1) \& (2) \& (4) } \\
\hline & & $\begin{array}{l}\text { Mean }{ }^{137} \mathrm{Cs} \\
\left(\mathrm{Bq} \mathrm{m}^{-2}\right)\end{array}$ & $\begin{array}{c}\text { Total }{ }^{137} \mathrm{Cs} \\
\mathrm{TBq}\end{array}$ & $\begin{array}{c}\% \text { of total } \\
\text { TBq }\end{array}$ & $\begin{array}{c}\operatorname{Mean}^{137} \mathrm{Cs} \\
\left(\mathrm{Bq} \mathrm{m}^{-2}\right)\end{array}$ & $\begin{array}{c}\text { Total }{ }^{137} \mathrm{Cs} \\
\mathrm{TBq}\end{array}$ & $\begin{array}{c}\% \text { of total } \\
\text { TBq }\end{array}$ & $\begin{array}{l}\operatorname{Mean}^{137} \mathrm{Cs} \\
\left(\mathrm{Bq} \mathrm{m}^{-2}\right)\end{array}$ & $\begin{array}{c}\text { Total }{ }^{137} \mathrm{Cs} \\
\mathrm{TBq}\end{array}$ & $\begin{array}{c}\% \text { of total } \\
\mathrm{TBq}\end{array}$ \\
\hline $\mathrm{OZ}$ & & $170 \pm 160$ & $5 \pm 5$ & $5.5 \%$ & $160 \pm 120$ & $5 \pm 4$ & $4.8 \%$ & $160 \pm 120$ & $5 \pm 4$ & $3.9 \%$ \\
\hline $\mathrm{MCZ}$ & & $1000 \pm 1100$ & $17 \pm 17$ & $17.6 \%$ & $1200 \pm 1000$ & $19 \pm 16$ & $18.3 \%$ & $1200 \pm 1000$ & $19 \pm 16$ & $14.8 \%$ \\
\hline SCZ & & $16000 \pm 13000$ & $52 \pm 45$ & $54.0 \%$ & $13000 \pm 6800$ & $44 \pm 22$ & $42.3 \%$ & $13000 \pm 8700$ & $42 \pm 29$ & $33 \%$ \\
\hline \multirow{2}{*}{$\mathrm{NCZ}$} & Greater area & $4500 \pm 2100$ & $21 \pm 10$ & $21.8 \%$ & $7300 \pm 5100$ & $35 \pm 24$ & $33.6 \%$ & $13000 \pm 11000$ & $61 \pm 52$ & $47.5 \%$ \\
\hline & $3 \mathrm{~km}$ radius & 73000 & 1 & $1.1 \%$ & 73000 & 1 & $1.0 \%$ & 73000 & 1 & $0.8 \%$ \\
\hline Total & & \multicolumn{3}{|c|}{$100 \pm 50 \mathrm{TBq}$} & \multicolumn{3}{|c|}{$100 \pm 40 \mathrm{TBq}$} & \multicolumn{3}{|c|}{$130 \pm 60 \mathrm{TBq}$} \\
\hline
\end{tabular}

yet composed only 9 and $6 \%$ of the total area, respectively (Tables $3 \mathrm{a}$ and $\mathrm{b}$ ).

Figures 5 and 6 show the spatial distribution of cesium inventories for all zones surrounding the FDNPP and illustrate both the high intrazonal variability and the overall decrease of inventories with depth. Included are cores from this study $(n=18)$, from the February 2012 MEXT sampling dates $(n=30$; Kusakabe, 2013), and from all OTKA dates $(n=20$; Otosaka and Kato, 2014), the latter two containing adjusted cesium inventories when applicable (see Sect. 3.5). Best-fit exponential regressions of these inventories versus water depth are shown in Fig. 6. As observed with the cores from this study, the complied inventories from 0 to $150 \mathrm{~m}$ in the NCZ and SCZ did not reflect a significant relationship with water depth $\left(R^{2}<0.01\right)$, which we suggest reflects the importance of grain size distribution in these zones (Fig. 3a).

\section{Conclusions}

Our ${ }^{137} \mathrm{Cs}$ sediment inventory estimates of 100 to $130 \mathrm{TBq}$ for $55000 \mathrm{~km}^{2}$ (0 to $4000 \mathrm{~m}$ water depth off Japan) represent the most comprehensive attempt to date for quantifying FDNPP cesium incorporation into marine sediments. The coastal sediments contain the majority of the total TBq delivered, with inventories ranging from 100 to $125 \mathrm{TBq}$ for
$24100 \mathrm{~km}^{2}$ (0 to $800 \mathrm{~m}$ water depth). With expanded spatial coverage inside the $30 \mathrm{~km}$ radius of the FDNPP and improved vertical resolution in the NCZ and SCZ, our coastal inventory estimates fall between the $38 \mathrm{TBq}$ of Kusakabe et al. (2013) and the $200 \mathrm{TBq}$ of Otosaka and Kato (2014). Kusakabe et al. (2013) had calculated only surface inventories for the upper $3 \mathrm{~cm}$ for a similar area, thus providing a lower limit for total coastal inventories. Otosaka and Kato's (2014) estimate of $200 \mathrm{TBq}$ is higher because it was calculated using exponential water depth versus cesium inventory relationships that were derived without any $\mathrm{NCZ}$ cores, which effectively applied the relatively elevated SCZ core inventories to the entire NCZ and SCZ (Fig. 5).

Our zonal analysis of cesium inventories, in conjunction with ${ }^{210} \mathrm{~Pb}_{\text {ex }}$ and grain size analyses, has provided an assessment of the total cesium inventory that will inform future studies. We have identified key areas where more cores may improve inventory estimates. First, additional sampling is needed to supplement sparse coverage in two regions: north of the FDNPP along the coast from 37.70 to $38.20^{\circ} \mathrm{N}$ in the MCZ, and in locations deeper than $2000 \mathrm{~m}$ in the OZ. With the large observed spatial variability from scales of $1 \mathrm{~m}^{2}$ (between multi-corer tubes) to $10000 \mathrm{~m}^{2}$ (among zones), greater numbers of cores are essential to better constrain our estimates at present. Second, while most MCZ and OZ cores are long enough to capture complete cesium inventories, in 


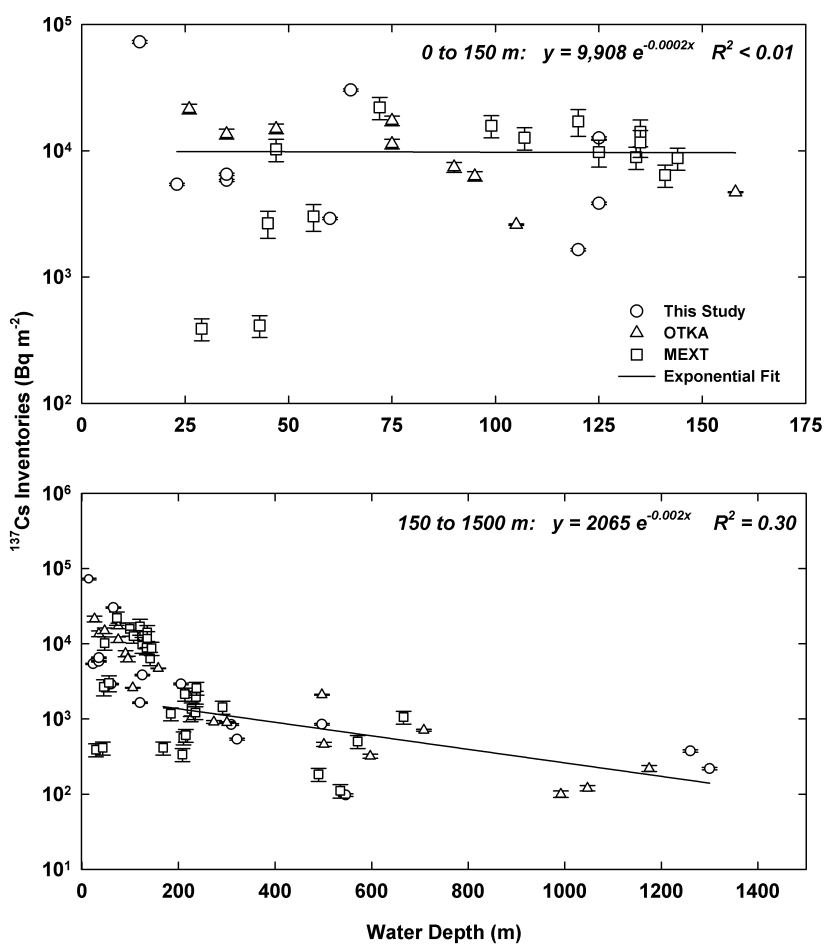

Figure 6. Spatial variations in ${ }^{137} \mathrm{Cs}$ sediment inventories with water depth. The measured and adjusted inventories from Fig. 5 are plotted against water depth. The upper figure shows the exponential regression for core inventories from 0 to $150 \mathrm{~m}$, excluding core 20 . The lower figure shows all inventories and the regression for cores located from 150 to $1500 \mathrm{~m}$.

the NCZ and SCZ cesium had penetrated deeper than 18 to $20 \mathrm{~cm}$. More extensive and deeper coring in both zones is needed to determine ultimate penetration depths and full inventories.

Both the relative inventories of cesium in the coastal environment and estimated zonal 'recovery' timescales have implications for bottom-dwelling biota and those that may consume demersal species. If we assume a total ${ }^{137} \mathrm{Cs}$ release to the ocean of approximately 15 to $30 \mathrm{PBq}$ from the Fukushima accident (Buesseler, 2014), our calculated sedimentary inventories comprise less than $1.0 \%$ of the total release in 2011. However, cesium concentrations in the water are decreasing and only $15 \mathrm{TBq}$ remain in coastal waters (Buesseler, 2014). Therefore, the sediment reservoir currently represents approximately 86 to $90 \%$ of the total ${ }^{137} \mathrm{Cs}$ inventory (water and sediment) off the coast of Japan. Rapid mixing in some locations may decrease biological access to these high activity sediments by transporting cesium isotopes deeper and therefore decreasing the overall activity of the more easily resuspended surface layers. While the MCZ and $\mathrm{OZ}$ require more time to reduce surface activities by $50 \%$, they do not pose as much of an environmental hazard because of their relatively low initial activities. The areas of greatest concern are the coastal zones shallower than $150 \mathrm{~m}$ water depth. Additional biological studies should take note of these zonal hot spots as cesium levels may remain elevated here much longer despite faster observed mixing rates.

In addition to bioturbation, other processes impacting cesium distributions in the coastal ocean require further study. Yamashiki et al. (2014) found that suspended particle loads in the Abukuma River basin near Fukushima delivered over $5 \mathrm{TBq}$ of cesium to the NCZ in a 10-month period. A typhoon that occurred during this time contributed more than half of this inventory over only 8 days. While $5 \mathrm{TBq}$ would account for only 4 to $5 \%$ of the total sediment reservoir, depending on where and how the particles are transported, this contribution could create local hot spots. Chemical remobilization rates of cesium from sediment pore waters have not been published for this area of Japan but are likely less than $0.1 \mathrm{TBq}$ per month for cesium, based on previous studies of the Irish Sea (Mitchell et al.,1999), and could decrease the total coastal inventory. Even though these source and loss terms are relatively small compared to the total cesium inventory of the sediments, only long-term monitoring within the study region will indicate whether decay alone or other factors are controlling cesium activities and distributions over the next decade.

\section{The Supplement related to this article is available online at doi:10.5194/bg-11-5123-2014-supplement.}

Acknowledgements. The authors would like to thank the captain, crew, and scientists aboard the R/V Tunsei Maru, R/V Mirai, R/V Umitaka Maru, and the R/V Daisan Kaiyo Maru. In particular, our samples were made possible by collaborations in the field with Jota Kanda, Jun Nishikawa, Makio Honda, and Shigeyoshi Otosaka. Field and laboratory assistance was provided by Crystal Brier, Stephanie Madsen, Chris Griner, and Steven Pike. The authors would also like to acknowledge the support of the Gordon and Betty Moore Foundation, Deerbrook Charitable Trust, Woods Hole Oceanographic Institution, and Massachusetts Institute of Technology.

Edited by: P. Povinec

\section{References}

Aller, R. C. and Cochran, J. K.: ${ }^{234} \mathrm{Th} /{ }^{238} \mathrm{U}$ disequilibrium in nearshore sediment: particle reworking and diagenetic time scales, Earth Planet. Sc. Lett., 29, 37-60, 1976.

Anderson, R. F., Bopp, R. F., Buesseler, K. O., and Biscaye, P. E.: Mixing of particles and organic constituents in sediments from the continental shelf and slope off Cape Cod: SEEP-I results, Cont. Shelf. Res., 8, 925-946, 1988.

Aoyama, M., Tsumune, D., and Hamajima, Y.: Budgets and temporal change of radiocaesium distribution released from Fukushima 
NPP accidents in the North Pacific Ocean, Ocean Sciences Meeting, Salt Lake City, Utah, 21 February 2012, Session 88, 2012.

Bowen, V. T., Noshkin, V. E., Livingston, H. D., and Volchok, H. L.: Fallout radionuclides in the Pacific Ocean: vertical and horiztonal distributions, largely from GEOSECS stations, Earth Planet. Sc. Lett., 49, 411-434, 1980.

Buesseler, K. O.: Fishing for answers off Fukushima, Science, 338, 480-482, 2012.

Buesseler, K. O.: Fukushima and ocean radioactivity, Oceanography, 27, 1-13, 2014.

Buesseler, K. O., Livingston, H., and Sholkovitz, E.: ${ }^{239,240} \mathrm{Pu}$ and excess ${ }^{210} \mathrm{~Pb}$ inventories alon gthe shelf and slope of the northeast USA, Earth Planet. Sc. Lett., 76, 10-22, 1985/1986.

Buesseler, K. O., Aoyama, M., and Fukasawa, M.: Impacts of the Fukushima Nuclear Power Plants on marine radioactivity, Environ. Sci. Technol., 45, 9931-9935, 2011.

Buesseler, K. O., Jayne, S. R., Fisher, N. S., Rypina, I. I., Baumann, H., Baumann, Z., Breier, C. F., Douglass, E. M., George, J., Macdonald, A. M., Miyamoto, H., Nishikawa, J., Pike, S. M., and Yoshida, S.: Fukushima-derived radionuclides in the ocean and biota off Japan, P. Natl. Acad. Sci. USA, 109, 5984-5988, 2012.

Charette, M. A., Breier, C. F., Henderson, P. B., Pike, S. M., Rypina, I. I., Jayne, S. R., and Buesseler, K. O.: Radium-based estimates of cesium isotope transport and total direct ocean discharges from the Fukushima Nuclear Power Plant accident, Biogeosciences, 10, 2159-2167, doi:10.5194/bg-10-2159-2013, 2013.

Chino, M., Nakayama, H., Nagai, H., Terada, H., Katada, G., and Yamazawa, H.: Preliminary estimation of release amounts of ${ }^{131} \mathrm{I}$ and ${ }^{137} \mathrm{Cs}$ accidentally discharged from the Fukushima Daiichi Nuclear Power Plant into the atmosphere, J. Nucl. Sci. Technol., 48, 1129-1134, 2011.

Cochran, J. K.: Particle mixing rates in the sediments of the eastern equatorial Pacific: evidence from ${ }^{210} \mathrm{~Pb},{ }^{239,240} \mathrm{Pu}$ and ${ }^{137} \mathrm{Cs}$ distributions at MANOP sites, Geochim. Cosmochim. Ac., 49, 1195-1210, 1985.

Cochran, J. K., McKibbin-Vaughan, T., Dornblaser, M. M., Hirschberg, D., Livingston, H. D., and Buesseler, K. O.: ${ }^{210} \mathrm{~Pb}$ scavenging in the North Atlantic and North Pacific Oceans, Earth Planet. Sc. Lett., 97, 332-352, 1990.

Currie, L. A.: Limits for qualitative detection and quantitative determination, Anal. Chem., 40, 586-593, 1968.

He, Q. and Walling, D. E.: Interpreting particle size effects in the adsorption of ${ }^{137} \mathrm{Cs}$ and unsupported ${ }^{210} \mathrm{~Pb}$ by mineral soils and sediments, J. Environ. Radioactiv., 30, 117-137, 1996.

Henderson, G. M., Lindsay, F. N., and Slowey, N. C.: Variation in bioturbation with water depth on marine slopes: a study on the Little Bahamas Bank, Mar. Geol., 160, 105-118, 1999.

Honda, M. C., Kawakami, H., Watanabe, S., and Saino, T.: Concentration and vertical flux of Fukushima-derived radiocesium in sinking particles from two sites in the Northwestern Pacific Ocean, Biogeosciences, 10, 3525-3534, doi:10.5194/bg-103525-2013, 2013.

Joydas, T. V. and Damodaran, R.: Infaunal macrobenthos along the shelf waters of the west coast of India, Arabian Sea, Indian J. Mar. Sci., 38, 191-204, 2009.
Kanda, J.: Continuing ${ }^{137}$ Cs release to the sea from the Fukushima Dai-ichi Nuclear Power Plant through 2012, Biogeosciences, 10, 6107-6113, doi:10.5194/bg-10-6107-2013, 2013.

Kusakabe, M., Oikawa, S., Takata, H., and Misonoo, J.: Spatiotemporal distributions of Fukushima-derived radionuclides in nearby marine surface sediments, Biogeosciences, 10, 50195030, doi:10.5194/bg-10-5019-2013, 2013.

Lee, S. H., Povinec, P. P., Wyse, E., Pham, M. K., Hong, G. H., Chung, C. S., Kim, S. H., and Lee, H. J.: Distribution and inventories of ${ }^{90} \mathrm{Sr},{ }^{137} \mathrm{Cs},{ }^{241} \mathrm{Am}$ and Pu isotopes in sediments of the Northwest Pacific Ocean, Mar. Geol., 216, 249-263, 2005.

Mitchell, P. I., Condren, O. M., Vintró, L. L., and McMahon, C. A.: Trends in plutonium, americium and radiocaesium accumulation and long-term bioavailability in the western Irish Sea mud basin, J. Environ. Radioactiv., 44, 223-251, 1999.

Moon, D., Hong, G., Kim, Y., Baskaran, M., Chung, C. S., Kim, S. H., Lee, H., Lee, S., and Povine, P. P.: Accumulation of anthropogenic and natural radionuclides in bottom sediments of the Northwest Pacific Ocean, Deep-Sea Res. Pt. II, 50, 2649 2673, 2003.

Nozaki, Y. and Tsunogai, S.: ${ }^{226} \mathrm{Ra},{ }^{210} \mathrm{~Pb}$ and ${ }^{210} \mathrm{Po}$ disequilibria in the western North Pacific, Earth Planet. Sc. Lett., 32, 313-321, 1976.

Nuclear Regulation Authority of Japan (NRA): Readings of Sea Area Monitoring in Marine Soil, available at: http://radioactivity. nsr.go.jp/en/list/247/list-1.html (last access: 10 February 2014), 2014a.

Nuclear Regulation Authority of Japan (NRA): Readings of Sea Area Monitoring in Sea Area by MEXT, available at: http://radioactivity.nsr.go.jp/en/list/260/list-1.html (last access: 10 February 2014), 2014b.

Oguri, K., Kawamura, K., Sakaguchi, A., Toyofuku, T., Kasaya, T., Murayama, M., Fujikura, K., Glud, R. N., and Kitazato, H.: Hadal disturbance in the Japan Trench induced by the 2011 Tohoku-Oki earthquake, Scientific Reports, 3, 1915, doi:10.1038/srep01915, 2013.

Otosaka, S. and Kato, Y.: Radiocesium derived from the Fukushima Daiichi Nuclear Power Plant accident in seabed sediments: initial deposition and inventories, Environ. Sci. Process. Impacts, 16, 978-990, doi:10.1039/c4em00016a, 2014.

Otosaka, S. and Kobayashi, T.: Sedimentation and remobilization of radiocesium in the coastal area of Ibaraki, $70 \mathrm{~km}$ south of the Fukushima Dai-ichi Nuclear Power Plant, Environ. Monit. Assess., 185, 5419-5433, 2013.

Poole, A. J., Denoon, D. C., and Woodhead, D. S., The distribution and inventory of ${ }^{137} \mathrm{Cs}$ in sub-tidal sediments of the Irish Sea, in: Radioprotection: Radionuclides in the Ocean Les Editions de Physique, France, 32, edited by: Germain, P., Guary, J. C., Gueguenait, P., and Metivier, H., 422 pp., 1997.

Povinec, P. P., Aoyama, M., Biddulph, D., Breier, R., Buesseler, K., Chang, C. C., Golser, R., Hou, X. L., Ješkovský, M., Jull, A. J. T., Kaizer, J., Nakano, M., Nies, H., Palcsu, L., Papp, L., Pham, M. K., Steier, P., and Zhang, L. Y.: Cesium, iodine and tritium in NW Pacific waters - a comparison of the Fukushima impact with global fallout, Biogeosciences, 10, 5481-5496, doi:10.5194/bg10-5481-2013, 2013.

Sakuna, D., Szczucinski, W., Feldens, P., Schwarzer, K., and Khokiattiwong, S.: Sedimentary deposits left by the 2004 Indian Ocean 
tsunami on the inner continental shelf offshore of Khao Lak, Andaman Sea (Thailand), Earth Planets Space, 64, 931-943, 2012.

Stohl, A., Seibert, P., Wotawa, G., Arnold, D., Burkhart, J. F., Eckhardt, S., Tapia, C., Vargas, A., and Yasunari, T. J.: Xenon133 and caesium-137 releases into the atmosphere from the Fukushima Dai-ichi nuclear power plant: determination of the source term, atmospheric dispersion, and deposition, Atmos. Chem. Phys., 12, 2313-2343, doi:10.5194/acp-12-2313-2012, 2012.

Tateda, Y., Tsumune, D., and Tsubono, T.: Simulation of radioactive cesium transfer in the southern Fukushima coastal biota using a dynamic food chain transfer model, J. Environ. Radioactiv., 124, 1-12, 2013.

Tokyo Electric Power Company (TEPCO): Measures for Water Leakage, available at: http://www.tepco.co.jp/en/nu/ fukushima-np/water/index-e.html (last access: 10 February 2014), 2014.

Thornton, B., Ohnishi, S., Ura, T., Odano, N., Sasaki, S., Fujita, T., Watanabe, T., Nakata, K., Ono, T., and Ambe, D.: Distribution of local ${ }^{137} \mathrm{Cs}$ anomalies on the seafloor near the Fukushima Daiichi Nuclear Power Plant, Mar. Pollut. Bull., 74, 344-350, 2013.

Tsunogai, S. and Harada, K.: ${ }^{226} \mathrm{Ra}$ and ${ }^{210} \mathrm{~Pb}$ in the western North Pacific, in: Isotope Marine Chemistry, edited by: Goldberg, E. D., Horibe, Y., and Saruhashi, K., Uchida Rokakuho Publishing Company, Tokyo, 165-191, 1980.
Ueno, T., Nagao, S., and Yamazawa, H.: Atmospheric deposition of ${ }^{7} \mathrm{Be},{ }^{40} \mathrm{~K},{ }^{137} \mathrm{Cs}$ and ${ }^{210} \mathrm{~Pb}$ during $1993-2001$ at Tokai-mura, Japan, J. Radioanal. Nucl. Ch., 255, 335-339, 2003.

Walbran, P. D.: ${ }^{210} \mathrm{~Pb}$ and ${ }^{14} \mathrm{C}$ as Indicators of Callianassid Bioturbation in Coral Reef Sediment, J. Sediment Res. A, 66, 259-264, 1996.

Yamamoto, M., Sakaguchi, A., Sasaki, K., Hirose, K., Igarashi, Y., and Kim, C. K.: Seasonal and spatial variation of atmospheric ${ }^{210} \mathrm{~Pb}$ and ${ }^{7} \mathrm{Be}$ deposition: features of the Japan Sea side of Japan, J. Environ. Radioactiv., 86, 110-131, 2006.

Yamashiki, Y., Onda, Y., Smith, H. G., Blake, W. H., Wakahara, T., Igarashi, Y., Matsuura, Y., and Yoshimura, K.: Initial flux of sediment-associated radiocesium to the ocean from the largest river impacted by Fukushima Daiichi Nuclear Power Plant, Scientific Reports, 4, 3714, doi:10.1038/srep03714, 2014.

Yang, H.-S., Nozaki, Y., Sakai, H., Nagaya, Y., and Nakamura, K., Natural and man-made radionuclide distributions in Northwest Pacific deep-sea sediments: rates of sedimentation, bioturbation and ${ }^{226}$ Ra migration, Geochem. J., 20, 29-40, 1985. 